九州大学学術情報リポジトリ

Kyushu University Institutional Repository

\title{
A Systematic Study of the Japanese Pipunculidae (Diptera) : Part III. The Genus Cephalops Fallen
}

Morakote, Rut

Entomological Laboratory, Faculty of Agriculture, Kyushu University

Hirashima, Yoshihiro

Entomological Laboratory, Faculty of Agriculture, Kyushu University

https://doi.org/10.5109/23897

出版情報：九州大学大学院農学研究院紀要. 34 (3)，pp. 183-214，1990-02. Kyushu University バージョン：

権利関係 : 


\title{
A Systematic Study of the Japanese Pipunculidae (Diptera) Part III. The Genus Cephalops Fallén
}

\author{
Rut Morakote and Yoshihiro Hirashima \\ Entomological Laboratory, Faculty of Agriculture, \\ Kyushu University, Fukuoka 812, Japan
}

(Received March 31, 1989)

\begin{abstract}
Thirteen species of the genus Cephalops Fallen are treated with key to species, descriptions and illustrations of important diagnostic characters. Three of them are newly recorded from Japan and nine of them are new to science.
\end{abstract}

\section{Subfamily PIPUNCULINAE}

This subfamily is characterized by having the plain and bare ocellar triangle, the well-developed occiput, the dorsum of the thorax without any bristles and the almost straight hind margin of eyes, It is the largest subfamily among three subfamilies in the family Pipunculidae and it is devided into two tribes. Eight genera of this subfamily are known in the world. In Japan, only three genera are found at present.

\section{Tribe PIPUNCULINI}

This tribe is characterized by having the coloration on the third costal section. Six genera of this tribe are known in the world but only three genera are found in Japan at present.

\section{Genus CEPHALOPS Fallen}

Cephalops Fallén, 1810, Ent. nov. Dipt., $10: 28$. Type species : aneus Fallén by monotypy. - Collin, 1956, Opus. ent., $21: 155$. Coe, 1966, Handbk. Ident. Brit. Ins., 10(2C): 54. -Meyer and Bruyn, 1985, Doc. Trav. inst. r. sci. Nat. Belg., 24 : 28. Kozanék, 1987, Annot. zool. bot., Bratislava, 180 : 1.

Cephalosphaera Enderlein, 1936, Dipt. Tierwelt Mitteleur., 4 : 129. Type species : Pipunculus furcatus Egger, 1860, by monotypy. - Aczél, 1939, 2001. Anz., 125 : 20 ; — , 1948, Acta 2001. Liloana, 6 : 73. -Hardy, 1943, Univ. Kans. Sci. Bull., 29: 40.

Collinias Aczél, 1940, Zool. Anz. 132 : 151. Type species : Pipunculus heterostigmus Perkins, 1905, by original designation.

*Contribution from the Entomological Laboratory, Faculty of Agriculture, Kyushu University, Fukuoka (Ser. 3, No. 303) 
Strandimyza Duda, 1940, Folia Zool. Hydrobiol., 10 : 216. Type species : Pipunculus furcatus Egger, 1860, by monotypy.

Anacephalops Aczél, 1940. Zool. Anz., 132 : 151. Type species :Pipunculus amboinalis Walker, 1861, by original designation.

Dorilas (Cephalosphaera): Hardy, 1950, Exploration du Parc Nat. Albert, Mission G. F. de Witte, $62: 4$.

The flies of this genus are characterized by having the propleural fan and the setae on the dorsum of the thorax are restricted only on each dorsocentral line. Hardy (1987) placed them as the subgenus of Pipunculus Latreille, and separated the species which posses the wing vein M2 from Pipunculus as the subgenus Cephalosphaera (as subgenus of Pipunculus Latreille). The present work followed Collin (1945) and Coe (1966b) which placed Cephalops as a distinct genus by the reason that the differentiation of setae on the dorsum of the thorax has the generic value but the wing vein M2 has no value.

To date, only two species have been recorded from Japan : C. pulvillatus (Kertész) by Hardy (1972) and C. furcatus by Yano et al. (1984). In this paper we record twelve more species including nine new species.

The Japanese flies in this genus are medium-sized with body length ranging from 3 to $6 \mathrm{~mm}$. The wings are generally much longer than its body. The body is usually bare, opaque grey to brown, or with some dusting on the dorsum of the thorax and abdomen. The abdominal segment 8 of male is generally with membranous area in varying shape. This character is good for species recognition.

Concerning the biology and host relationships, there are some publications (Hardy, 1964 ; Rothschild, 1964 ; Coe, 1966b ; Waloff, 1975 ; May, 1979) which indicated that they parasitized the homopterous insects of the family Delphacidae.

Key to the Japanese species of CEPHALOPS

1. Wings vein M2 present on the last section of wing vein Ml ..I..., ........... 2

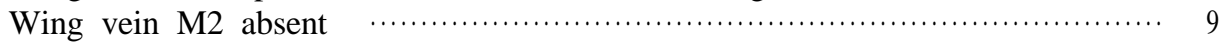

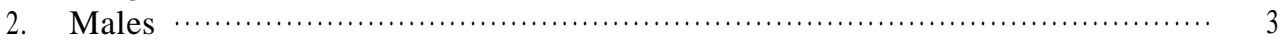

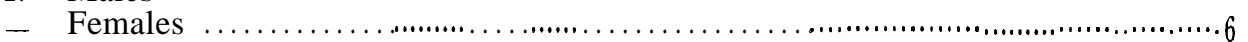

3. Four posterior femora with a tuft of many long pale pubescence beneath near' base, hind tibiae with postero-apical projection $\ldots \ldots \ldots \ldots \ldots \ldots \ldots . . \ldots 4$

- All femora without any long pale pubescence beneath, hind tibiae without posteroapical projection ; tibiae with incomplete black ring on apical two-thirds from posterior, tergite 8 without membranous area ; see Fig. 33 .................................. C. honshuensis Morakote, sp. n.

4. Abdomen shorter than its thorax, rather stout; abdominal tergites much wider than long ; femora extensively yellow at base especially on hind femora, about basal half and apical seventh ; wing vein M2 very short, about as long as r-m cross-vein ; see Fig. 32

C. sapporoensis Morakote, sp. $\mathrm{n}$.

Abdomen slightly longer than its thorax, parallel-sided, femora mainly

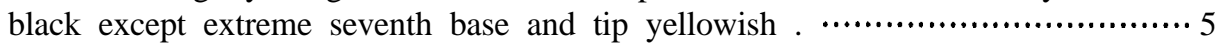


5. Third antennal segment incline yellow ; bristles beneath second antennal segment pale ; tibiae entirely yellowish; epandrium and surstyli of dry specimens only slightly protruded and scarcely seen from side; see Fig. 29

C. furcatus (Egger)

- Third antennal segment black bristles beneath second antennal segment black; tibiae with brownish black ring on middle third ; epandrium and surstyli of dry specimens considerably protruded and clearly seen from side ; see Fig. $34 \ldots \ldots \ldots \ldots \ldots \ldots \ldots \ldots$ C. hirashimai Morakote, sp. n.

6. Frons very narrow, parallel-sided, third antennal segment bright yellow, long acuminate ; all femora almost entirely yellow except dorsal of mid femora and ventral of hind femora with brownish streak ; ovipositor piercer very long, almost twice as long as base, tapering; see Fig. 31

C. hikosanus Morakote, sp. n.

Frons rather wide, slightly convex at middle

7. Third antennal segment black, scutellum without marginal bristles ; tibiae with incomplete black ring on apical two-thirds from posterior ; ovipositor piercer (Fig. 33F) as long as base, rather short when compar-

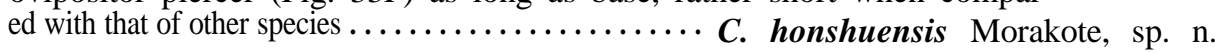

- Third antennal segment inclined yellow ; scutellum with 4-8 marginal bristles

8. Bristles beneath second antennal segment black ; tibiae entirely yellowish ; ovipositor piercer (Fig. 35A and C) • . ..".................... C. furcatus (Egger)

- Bristles beneath second antennal segment black ; tibiae with brownish black ring on middle third ; ovipositor rather short and stout than that of furcatus; piercer (Fig. 35B and D) rather thick as seen from side and very broad when viewed from ventral …........ C. hirashinai Morakote, sp. n.

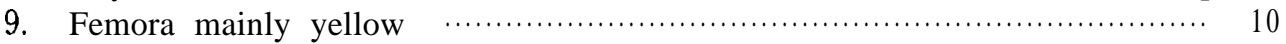

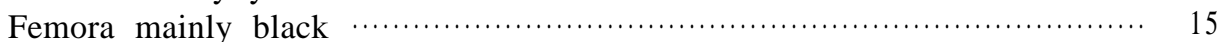

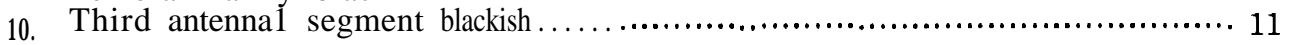

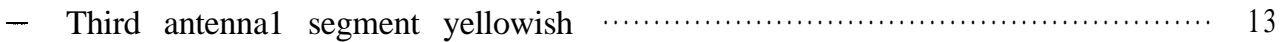

11. Femora with black ring near base, this ring extending posterodorsally as a pointed streak to near apex, wing rather long in proportion to the body ; genitalia as shown in Fig. 45, A and B ; female ovipositer (Fig. 38B) with conspicuous two lobes of protuberance at base of piercer

C. annulipes (Zetterstedt)

Femora entirely yellow

12. Last section of wing vein $\mathrm{Ml}$ very undulating (Fig. 39A); third antennal segment oval; abdominal tergites subshining black ; genital surstyli (Fig. 46B) rather large and long when compared with its genital epandrium ; female ovipositor (Fig. 39B) …..................... C. aneus Fallen

- Last section of wing vein Ml almost straight; third antennal segment short acuminate; abdominal tergites 2-4 with contrasting band of black anteriorly and grey posteriorly ; apex of subcostal vein not reached costal vein ; male abdominal terminalia as shown in Figs. $42 \mathrm{~B}$ and $44 \mathrm{~A}$

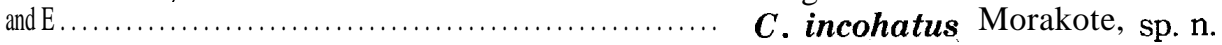

13. Humeri black; abdominal segments 3-5 metallic black on dorsum; 
genitalia very much protruded as seen from side ; male abdominal terminalia as shown in Figs. 42F, 43D and 44G

C. metallicus Morakote, sp. n.

- Humeri dull luteous

14. Abdominal tergites subshining grey on dorsum ; tergites 2-4 pale brown on posterior side corners ; genital epandrium and surstyli as shown in Fig. 46, C and D ; female ovipositor (Figs. 40B) -.. C. pacatus Morakote, sp. n.

- Abdominal tergite with contrasting band of black anteriorly and grey posteriorly ; third costal section of wing about 1.5 times as long as fourth ; abdominal terminalia as shown in Figs. 42D and 44B.

\section{C. yoshiyasui Morakote, sp. n.}

15 Third antennal segment oval, yellowish, abdominal tergites subshining brown ; abdominal terminalia as shown in Figs. 42H and 44C

\section{C. kumatai Morakote, sp. n.}

Third antennal segment short acuminate, blackish ; abdominal tergites 4 and 5 polish black on dorsum ; genital surstyli and epandrium very much protruding as seen from side ; tibiae with incomplete black ring at middle third from posterior ; abdominal terminalia as shown in Figs. $42 \mathrm{C}, 43 \mathrm{C}$ and $44 \mathrm{H}$

C. obtusinervis (Zetterstedt)

\section{Cephalops furcatus (Egger)}

Pipunculus furcatus Egger, 1860, Verh. Zool-bot. Ges. Wien., 10 : 347.

Strandimyza furcatus : Duda, 1940, Folia 2001. hydrobiol., $10: 216$.

Cephalosphaera furcata: Aczél, 1940, 2001. Anz., 132: 164.

Cephalops furcatus : Coe, 1966, Handbk. Ident. Bri. Ins., 10(2c): 55. - M e y e r a n d Bruyn, 1985, Doc. Trav. Inst. r. sci. Nat. Belg., 24 : 29. —-Kozanék, 1987, Annot. zool. bot., Bratislava, $180: 4$.

Pipunculus (Cephalops) furcatus : Yano et al., 1984, Trans. Shikoku ent. Soc., 16(4): 64.

Male.

Head (Fig. 29B) with eyes joined on upperpart of frons for about twice as long as frontal triangle ; frons and face silvery ; ocellar triangle shining black ; occiput cinereous, moderately thick, about one-fifth as long as eyes length ; antennae (Fig. 29C) rather small, first and second segments dull black, the latter with a few short black bristles above and longer pale bristles beneath ; third segment yellowish, acuminate, about twice as deep as second ; arista black, only slightly longer than third.

Thorax dull, chocolate color on dorsum but notopleural areas cinereous, almost bare but with moderately dense pale pubescence on notopleuron and a row of short pubescence on each dorsocentral line ; scutellum (Fig. 29D) cinereous, with 4-6 short black bristles; pleurae cinereous.

Legs mainly yellow, except coxae, femora and last tarsal segments brownish black ; hind femora yellowish at base and tip ; mid femora with posteromedial fringe of many long fine pale pubescence, with two rows of many black spines beneath from near base to subapical tip; hind femora (Fig. 29E) polished beneath, with anteroventral and posteroventral rows of black spines from near middle to tip, with numer- 
ous long pale fine pubescence beneath near base ; hind tibiae with posteroapical projection ; last tarsal segment brownish, long and narrow ; pulvilli short, about half as long as last tarsal segment.

Wings (Fig. 29A) hyaline ; stigma dark brown, extending back to tip of Sc; third costal section about twice as long as fourth, $\mathrm{r}-\mathrm{m}$ situated about basal three-sevenths of discal medial cell, placed at level of tip of $\mathrm{SC}_{\mathrm{C}}$; vein $\mathrm{M} 2$ present at basal one-third to one-fourth of last section of vein Ml, its length are variable but never reaching wing margins ; halteres with long stem and moderately large knob, brownish ; calypteres yellow.

Abdomen (Fig. 29G-K) slightly longer than thorax ; all tergites sparsely covered with short pale pubescence but tergite 1 with a brush of about 4-6 long black bristles anterolaterally ; tergites $1-4$ and 8 almost equal in length ; tergite 5 largest about 1.4 -1.6 times as wide as long and about three times as long as tergite 8 ; tergite 1 entirely cinereous ; tergites 2-5 extensively cinereous but with contrasting black of narrow band anteriorly ; a membranous area on tergite 8 clearly seen from behind, it extending to nearly posterior margin of epandrium.

Genitalia rather small ; slightly protruded, scarcely seen from side ; surstyli (Fig. 34C) rather large when compared with epandrium, symmetrical, triangular shape ; ejaculatory apodeme as shown in Fig. 34D.

Length : Body $5.3 \mathrm{~mm}$; wing $6.7 \mathrm{~mm}$

\section{Female.}

Differing from the male as follows : Eyes widely separated ; frons slightly concave at middle, with a row of short pale hairs along lateral margin,; front ommatidial facets of eyes slightly enlarged ; hind tibiae without posteroapical projection. Ovipositor (Fig. 35A and C) rather large, with base oval and cinereous ; piercer long and slender, about 1.2-1.3 times as long as base, slightly downcurved apically.

Length : Body 4-5 mm ; wing 5.2-6.5 mm

Specimens examined : (Kyushu) $1 \sigma^{7}$, Mt. Kurodake, Oita Pref., 27. v. 1985 ;6우우, Mt. Hikosan, Fukuoka Pref., 23. v. 1985 ; (Honshu) 107, Iitatemura, Mt. Abukuma, Fukushima Pref., 7. vii. 1985 (R. Morakote) ; $1 \sigma^{\pi}$, Dainichi-damu, Is, Awaji-shima, Hyogo, 10. iv. 1971 (K. Tobi) ; $10^{7}$, Mirozu, Susami, Wakayama, 12. iv. 1972 (K. Yamagishi) ;1우, Unkouji, Akazu, Seto, Aichi, 29. iv. 1972 (H. Yamada). (Hokkaido) 2 ఠフ Morakote).

Host : Unknown.

Distribution: Japan (Hokkaido, Honshu, Kyushu), Europe.

\section{Cephalops hirashimai Morakote, sp. n}

\section{M ale.}

Differing from the male of furcatus as follows: Third antennal segment black ; second segment with long black bristles beneath ; tibiae with brownish black ring on middle third ; tergite 5 about twice as wide as long; genitalia much protruded and clearly seen from side ; surstyli differ from those of furcatus as shown in Fig. 34A and B. 
Length : Body 4-5 mm; wing 5.2-6.2 mm.

\section{Female.}

Differing from the female of C. furcatus as follows : Tibiae entirely yellowish ; ovipositor (Fig. 35B and D) rather stout, shorter than that of furcatus; piercer thick when viewed from side and rather broad in dorsal view.

Length : Body 3.8-4.5 mm ; wing 5-6.2 mm.

Holotype: ه (Type No. 2728, Kyushu Univ.), Hitsujigaoka, Sapporo, Ishikari, 23. vi. 1986, Hokkaido (R. Morakote).

Paratypes: 5 우우, same data as holotype ; (Kyushu) Mt. Hikosan, Fukuoka Pref., 1 우, 21. v. 1986 ; 1 우, 28. v. 1986 ; 1 우, Mt. Kurodake, Oita Pref., 27. iv. 1985 ; (Honshu) 1 우, Boudotoge, Asahimura, Niigata Pref., 2. vii. 1985 (R.Morakote). $2 \sigma^{7} \sigma^{7}$, Uradani, Kitashitara, Aichi, 15-16. v. 1971 (S.Ohkusa) ;1 §7, Uradani, Shitara, Aichi, 15. v. 1971 (K. Tobi) ;1우, Nisshin, Aichi-gun, Aichi, 5. v. 1970 (K. Yamagishi) ;1우, Komagahara, Kitashitara, Aichi, 22. v. 1963 (T. Kunou) ; 1 우, Mt. Sanage-yama, Aichi, 2. v. 1971 (K. Yamagishi). (Hokkaido) 3 우우, Nukabira, Kamishihoro, Tokachi, 28-29, vi. 1986 ;5 우 우, Misumai, Sapporo, Ishikari, 24. vi. 1986 ; 5 우우, Iwabetsu-kawa, Utoro, Abashiri, 7. vii. 1986 ; 2 우우, Saroma, Abashiri, 10. vii. 1986. All were collected by R. Morakote. 1 우, Nopporo, 2, vi. 1968 (M. Suwa). $1 \sigma^{\Im}$, Mt. Tensan (900 m), Saga Pref., Kyushu, 5. v. 1986 (Y. Hirashima) ;3 $3 \sigma^{\top 7}$, Mt. Kuju, Oita Pref., Kyushu, 10. v. 1986 (T. Goto); 1 우, Nopporo, Sapporo, Hokkaido, 8. vi. 1985 (M. Abe).

Host : Unknown.

Distribution: Japan (Hokkaido, Honshu, Kyushu).

Cephalops hikosanus Morakote, sp. n.

\section{Female.}

Head (Fig. 31E) large, almost as wide as deep when viewed from side ; occiput cinereous, thickened, about one and a quarter as long as the length of eyes, with some short pale fine pubescence ; frons greatly narrow, almost parallel-sided, with a row of short pale hairs along each lateral margin; antennae (Fig. 31F) small ; first and second segments brownish black, the latter with some short bristles above and longer beneath, third segment pale yellowish, moderately long acuminate ; arista black, slightly longer than third segment.

Thorax and scutellum almost bare, chocolate color on dorsum ; notopleuron cinereous, with some pale hairs ; propleural fan with long pale bristles.

Legs almost entirely yellow, except coxae, middle of femora and last tarsal segments brownish black to black ; femora rather short and stout ; mid femora with two serrulated rows of small black spines beneath from near base to tip ; front and hind femora with anteroventral spines near apex.

Wings (Fig. 31A) hyaline ; stigma dark brown, extending back to tip of Sc; third costal section about twice as long as fourth ; r-m situated much beyond level of tip of Sc, placed slightly before middle of discal medial cell ; vein M2 present at about basal two-sevenths of last section of vein Ml, rather long, slightly shorter than posterior cross vein.

Abdomen (Fig. 31B and C) slightly longer than thorax, dull greyish, when viewed 
from above gradually widening from segment 1 to segments 2 and 3, and then narrowing again to tergite 6 ; tergite 2 largest ; ovipositor with oval base ; piercer very long, slender and almost straight, yellowish.

Length : Body $5 \mathrm{~mm}$; wing $5.6 \mathrm{~mm}$.

Holotype: 우 (Type No. 2729, Kyushu Univ.), Mt. Hikosan, Fukuoka Pref., Kyushu, 5. ix. 1985 (R. Morakote).

Host : Unknown

Distribution: Japan (Kyushu).

Remarks : This species very resembles to $C$. reduncus Hardy but is different from it as follows : Head as deep as long; the black humeri (yellow brown in reduncus), the femora with a brownish black marking around middle third (entirely yellow in reduncus), the third costal section of wing about twice as long as the fourth (about one-half in reduncus and the ovipositor piercer almost straight (curved upward at its apex in reduncus).

\section{Cephalops honshuensis Morakote, sp. n.}

Male (Fig. 33A-E).

Mostly resembling as the male of C. furcatus but differing by having the following : Third abdominal segment brownish black and bristles of second segment all black ; scutellum without.. any marginal bristles ; femora mainly black except extreme oneseventh of base and tip yellowish ; tibia mainly yellow but with incomplete brownish black ring on apical two-thirds from posterior ; hind tibiae without posteroapical projection ; abdominal tergite 8 about 0.16 times as long as tergite 5 , without membranous area.

Length : Body $5.5 \mathrm{~mm}$; wing $7.7 \mathrm{~mm}$.

\section{Female.}

Differing from the male as follows : Eyes widely separated f frons almost parallel-sided but slightly convex at middle, entirely cinereous, with a row of short pale hairs along each lateral margin ; vein $\mathrm{r}-\mathrm{m}$ of wing situated much after basal one-third of discal medial cell and vein M2 placed about basal one-fourth of last section of vein $\mathrm{Ml}$; ovipositor (Fig. 33F) with base and piercer equal in length and clearly different from that of C. furcatus.

Length: Body $5 \mathrm{~mm}$; wing $6.5 \mathrm{~mm}$.

Holotype: $\sigma^{7}$, Honshu, no date (K. Kamijo), in the collection of Hokkaido University.

Paratype: 1 우, Honshu, no date (K. Kamijo), in the collection of Hokkaido University.

Host : Unknown.

Distribution : Japan (Honshu).

Cephalops sapporoensis Morakote, sp. n.

Male (Fig. 32A-F).

Differing from the male of C. furcatus as follows : Antenna all black, the bristles 
of second antennal segment all black ; scutellum with 6 black marginal bristles ; fore and mid femora mainly black but basal third and extreme one-seventh of apex yellow ; hind femora with basal half and extreme one-seventh yellow ; wing vein M2 very short, about as long as of vein $\mathrm{r}-\mathrm{m}$, placed about basal third of discal medial cell ; abdomen rather short and stout, sligthly shorter than its thorax ; all tergites much wider than long, tergite 2 widest, about four times as wide as long ; tergite 5 longest ; membranous area on tergite 8 very large, heart shape, occupying almost entirely of apex, clearly seen from behind.

Length : Body $4.5 \mathrm{~mm}$; wing $6.2 \mathrm{~mm}$.

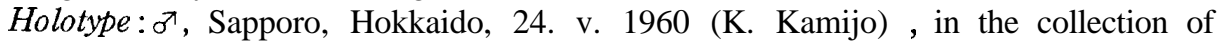
Hokkaido University.

Host : Unknown

Distribution : Japan (Hokkaido).

\section{Cephalops annulipes (Zetterstedt)}

Pipunculus annulipes Zetterstedt, 1838, Ins. Lapp. : 580. ——Kertész, 1900, Wien. ent. Ztg., $19: 245$.

Pipunculus vittipes Zetterstedt, 1844, Dipt. Scand., $3: 963 .-$ Verrall, 1901, British Flies, $8: 106$.

Cephalops vittipes : Coe, 1966, Handbk. Ident. Brit. Ins., 10 (2c): 61. - M e y e r a n d Bruyn, 1985, Doc. Trv. Inst. r. sci. Nat. Belg., 24 : 33. - Kozanék, 1987, Annot. zool. bot. Bratislava, $180: 9$.

Male (Fig. 38A).

Head : Occiput cinereous, moderately thick, about one-fifth of eyes length ; eyes joined for a distance about twice as long as frontal triangle ; frontal triangle and face silvery at some angle; antennae rather small ; all segment dull black ; second segment with a few short black bristles above and longer beneath, third segment oval, about twice as deep as second; arista enlarged at base, remainder tapering, slightly longer than third segment.

Thorax and scutellum subshining black, with obscurely brownish to greyish dusting on dorsum, thorax with a row of scarsely seen short hairs which restricted on each dorsocentral line ; pleurae bare but propleurae with a brush of about 8-10 long black bristles ; scutellum with many short fine marginal pubescence.

Legs with black coxae; femora extensively yellow, with brownish black ring near base, this ring extending posterodorsally as pointed streak to nearly tip ; trochanters, tibiae and tarsi yellow except last tarsal segment brownish black ; pulvilli slightly smaller than last tarsal segment; all femora with surrulated row of small black spines beneath.

Wings rather long in proportion to body, hyaline ; stigma dark brown, extending back to tip of Sc; third costal section long, about twice as long as fourth ; r-m situated slightly before level of tip of Sc, placed at basal one-third to one-fourth of discal medial cell ; last section of fourth vein almost straight ; halteres with narrow stem and small round knob, dull brown ; calypteres yellowish.

Abdomen when viewed from above subshining black except tergite 1 cinereous, 
parallel-sided to tergite 5 ; tergite one shortest ; tergite 5 longest, about three times as long as tergite 1 ; tergites $2-5$ almost equal in length; tergite 8 with roughly oval membranous area at right side. Genitalia as shown in Fig. $45 \mathrm{~A}$ and B.

Female.

Resembling the male but differing as follows : Eyes widely separated ; frons slightly concave at middle ; humeri inclined brownish ; ovipositor (Fig. 38B) with large oval base ; piercer short, conical shape, about as long as base ; base of piercer shining brownish black, with two conspicuous protuberant lobes above.

Length : Body $5.5 \mathrm{~mm}$; wing $6.0 \mathrm{~mm}$.

Specimens examined. (Hokkaido) 3 mating pairs, Raus Onsen, Nemuro, 8. vii. 1986 ; 1 mating pair, Nukabira, Kamishihoro, Tokachi, 28. vi. $1986 ; 2 \sigma^{\nearrow} \sigma^{\nearrow}$, Misumai, Sapporo, Ishikari, 23-24. vi. 1986 ; 16, Shunbetsu, Nemuro, 5. vii. 1986 ;18 줌우, Sounkyo, Mt. Daisetsu, Kamikawa, 26. vi. 1986. All were collected by R. Morakote. 162 우우,

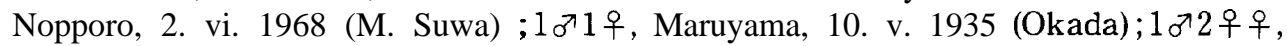
Sapporo, 6. vi. 1968 (M. Suwa). (Honshu) 16, Tokyo, 28. v. 1967 (H. Takizawa) ;1 $10^{7}$, Mt. Momokura, Yamanashi Pref., 25. v. 1987 (M. Suwa) ;1 $1 \sigma^{7}$, Tottori Pref., 9. vii. 1966 (T. Okadome) ;1 శ7, Mt. Gozaisho, Mie Pref., no date (T. Okadome) ;1 $\sigma^{7}$, Mt. Mitake, Tokyo, 28. v. 1967 (H. Takizawa) ;1 $\sigma^{7}$, Subashiri, Shizuoka, 30. v. 1959 (K. Kamijo) ; 1 우, Komaba, Tokyo, 7-5-1915 (S. Hirayama) ;1 $\sigma^{7}$, Komogahara, Kitashitara-gun, Aichi, 22. v. 1968 (T. Okadome) ;1ð, Mt. Hayachinesan, Iwate, 17. vi. 1969 (Y. Arita). (Kyushu) $2 \sigma^{7} \sigma^{7} 1$ 우, Mt. Hikosan, Fukuoka Pref., 7. v. 1986 ; same locality :5 $5 \sigma^{7} \sigma^{7} 4$ 우우,

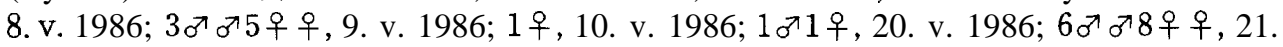
v. $1986 ; 1 \sigma^{7} 10$ 우우, 22. v. $1986 ; 1 \sigma^{7}, 23$. v. $1986 ; 3 \sigma^{7} \sigma^{7} 5$ 우우, Mt. Kurodake, Oita Pref., 28. v. 1986. All were collected by R. Morakote. 1శ', Mt. Hikosan, Fukuoka Pref., 20. iv. 1969 (Hikosan Biol. Lab. coll.); 1 우, Mt. Makabaki, Miyasaki Pref., 6. iv. 1978 (T. Goto) ; 16, Chojabaru, Mt. Kuju, Oita Pref., 10. v. 1986 (T. Goto) ; 1 우, same locality, 16. v. 1986 (M. Abe) ;1우, Mt. Hiko, 16. v. 1967 (H. Takizawa).

Host : Unknown.

Distribution : Japan (Hokkaido, Honshu, Kyushu), Europe.

Remarks : This is the first record of this species from Japan.

\section{Cephalops aneus Fallén}

Cephalops aneus Fallen, 1810, Specimen Ent., : 25 ; —CCo, 1966, Handbk. Ident. Brit. Ins., 10(2C): 55. -Meyer and Bruyn, 1985, Doc. Trav. Inst. r. sci. Nat. Belg., 24 : 28. Kozanék, 1987, Annot. zool. bot., Bratislava, $180: 7$.

Pipunculus flavipes Meigen : 1824, Syst. Beschr., $4: 21$.

Both male and female of this species are very similar to C. annulipes but different as describing belows:

Male (Fig. 39A).

Thorax and abdomen more shining black on dorsurn ; humeri dull brown ; legs entirely yellow except coxae; wing long but not so much long as annulipes, last section of wing vein Ml very undulating; abdominal tergite 8 different from that of annulipes as shown in Figs. 42E and 44F. 
Female.

Differing from the female C. annulipes as follows : Smaller, abdomen rather slender and more shining black ; legs entirely yellow, wings with last section of vein Ml very undulating; ovipositor (Fig. 39B) smaller ; base of piercer flattened above.

Length : Body : 3.5-4.2 mm; wing 5-5.5 mm.

Specimens examined. (Hokkaido) :1 mating pair, Nukabira, Kamishihoro, Tokachi, 29. vi. $1986 ; 1 \sigma^{\nearrow 1} 1$ 우, ditto ; $4 \sigma^{7} \sigma^{7}$, same locality, 28. vi. $1986 ; 21 \sigma^{7} \sigma^{71} 1$ 우, Sounkyo,

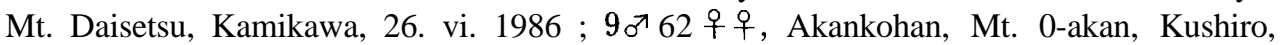
5. vii, 1986 ;1 $1 \sigma^{7} 4$ 우우, Raus Onsen, Nemuro, 8. vii. 1986. All were collected by R. Morakote. 1 우, Ashoro, Tokachi, 12. vi. 1985 (M. Abe) ; 13겅 63 우우, Rubesu, Shibetsu, Nemuro, 25. viii. 1971; 1 우, Betsukari, Mashike, Rumoi, 20-23. viii. 1971 (K. Yamagishi) ;1우, Apoi, 21. viii. 1957 (T. Kumata) ;1우, Apoi, 22. vi. 1959 (K. Kamijo) ;1우, Sapporo, no date, S. Takagi ;1 $\sigma^{7}$, Sapporo, 2. vi. 1968 (M. Suwa) ; 16, Shikaribetsu, 24. viii. 1934 (Okada); $1 \sigma^{\nearrow}$, Apoi, 22, vi. 1959 (T. Kumata). (Honshu) 1ळ, Mt. Sanageyama, Toyota, Aichi Pref., 14. v. 1971 (H. Yamada);1 고, Hakkoda, Aomori, 19. viii. 1966 (M. Suwa).

Host : Unknown.

Distribution : Japan (Hokkaido, Honshu), Europe.

Cephalops pacatus Morakote, sp. n.

Male (Fig. 40A).

Eyes joined on upper part of frons for about 1.5 times as long as frontal triangle, frontal triangle and face silvery ; occiput cinereous, about one-fifth as long as eyes' length ; third antennal segment yellow, oval about one half as deep as second ; arista black, slightly longer than third segment.

Thorax and scutellum bare, dull greyish ; humeri dull luteous ; pleurae black ; propleural fan pale.

Legs almost entirely bright yellow, except four anterior coxae and last tarsal segments black ; mid femora with two serrulated rows of small black spines beneath from near base to tip ; front tibiae with posteroapical spur ; pulvilli small, about half as long as last tarsal segment.

Wings hyaline, elongate ; stigma brownish, extending back to tip of $\mathrm{S} \mathrm{C}$, about 1.5 to two times as long as fourth ; r-m situated about basal one quarter of discal cell, last section of vein Ml long, almost straight ; halteres with long and narrow stem and round knob; calypteres yellow.

Abdomen moderately longer than thorax, when viewed from above tergite 1 entirely cinereous, with a brush of 6-7 pale pubescence anterolaterally ; other tergites subshining brownish to greyish black; posterolateral corners of tergites 2 and 3 obscurely brownish pale ; tergite 5 largest, moderately longer than wide ; tergite 8 very short on dorsum, about one-third as long as tergite 5 ; with membranous area ; membranous area small, clearly seen from behind, scarcely seen from above, occupying almost half of segment on the right side of tergite 8 .

Genitalia very resemble those of C. annulipes but epandrium and surstyli are different from it in shape and size, as shown in Fig. 46, C and D. 


\section{Female.}

Very resembling the male but differing as follows : Eyes widely separated ; frons slightly concave at middle, with a row of short fine hairs along each lateral margin. Ovipositor (Fig. 40B) small ; ovipositor base black, globular ; ovipositor piercer yellow, short and aculeus, about as long as ovipositor base, with small protuberance at its base.

Length : Body 3-4 mm; wing 4.3-4. $8 \mathrm{~mm}$.

Holotype: $\sigma^{7}$ (Type No. 2730, Kyushu Univ.), Mt. Hikosan, Fukuoka Pref., Kyushu, 19. vi. 1985 (R. Morakote).

Paratypes: same data as holotype (Kyushu) $7 \sigma^{7} \sigma^{7} 6$ 우우; 16, same locality, 22. v. 1985 ; (Honshu) $2 \sigma^{7} \sigma^{7} 1$ 우, Iitatemura, Mt. Abukuma, Fukushima Pref., 18. vii. 1985 ;2 우우, Goshikinuma, Urabandai, Fukushima Pref., 9. vii. 1985 ;3우우, Natsui, Kurokawa-mura, Niigata, Pref., 3. vii. 1985 ;1우, Nakatsugawa, Mt. Azuma, Fukushima Pref. 10. vii. 1985 ; 1 우, Futakuchi keikoku, Akui-machi, Miyagi Pref., 12. vii. 1985 ; (Hokkaido) 1우, Sounkyo, Mt. Daisetsu, Kamikawa, 26. vi. 1986 ; 1 우, Hokkaido Univ., Sapporo, Ishikari, 22. vi. 1986 ;1 우, Hitsujigaoka, Sapporo, Ishikari, 23. vi. 1986 ; 1우, Ashoro, Tokachi, 30. vi. 1986 ; Akankohan, Mt. 0-akan, Kushiro, 4. vii. 1986 ;2 우 우, Raus Onsen, Nemuro, 8. vii. 1986. All were collected by R. Morakote.

Host : Unknown.

Distribution: Japan (Hokkaido, Honshu, Kyushu).

\section{Cephalops obtusinervis (Zetterstedt)}

Pipunculus obtusinervis Zetterstedt, 1944, Dipt. Scand., 3 : 965. - Verrall, 1901, Brit. Flies, $8: 93$.

Cephalops obtusinervis : Coe, 1966, Handbk. Ident. Brit. Ins., 10(2C): 57. —— Kozanék, 1987, Annot.Zool. bot. Bratislava, $180: 11$.

M ale (Fig. 41B).

Eyes joined on upper part of frons for about length of frontal triangle ; frontal triangle and face silvery ; occiput cinereous, about one-fifth as long as eyes length ; antennae all brownish black ; third segment short acuminate ; arista black, slightly longer than third.

Thorax and scutellum, chocolate color on dorsum ; notopleuron and pleurae cinereous ; propleural fan black.

Legs with black coxae, yellowish brown trochanters ; femora mostly black except one-seventh of apex brownish ; tibiae brownish, with obscurely brownish black marking around middle third posteriorly ; tarsi brownish except last tarsal segments black ; femora brightly polished behind along lower part.

Wings hyaline, stigma brownish, extending back to tip of $\mathrm{SC}_{\mathrm{C}}$; third costal section about one half as long as fourth, r-m situated about middle of discal medial cell ; last section of vein Ml slightly undulating.

Abdomen when viewed from above with tergites 1-3 dull black with greyish dust posteriorly; tergites 4 and 5 entirely polished black ; tergites 1-4 almost equal in length, tergite 5 longest about 1.5 times as long as tergite 1; tergite 8 (Figs. 42C, 43C and $44 \mathrm{H}$ ) much wider than long, with triangular membranous area occupying nearly 
half of segment on the right side which is scarcely seen from above.

Genitalia with epandrium and surstyli very much protruding as seen from side ; surstyli moderately large when compared with its epandrium (Figs. 42C and 44C).

Length $3.2 \mathrm{~mm}$; wing $4.2 \mathrm{~mm}$.

Specimens examined : 16, Akankohan, Mt. 0-akan, Kushiro, 4. vii. 1986 (R. Morakote) ;1 $1 \sigma^{7}$ Mt. Soranuma-dake, Hokkaido, 7. vi. 1985 (M. Abe).

Host : Unknown.

Distribution : Japan (Hokkaido), Europe.

Cephalops metallicus Morakote, sp. n.

Male (Fig. 41A).

Eyes joined on upper part of frons for about twice as long as frontal triangle ; frontal triangle and face silvery ; occiput cinereous, about one-fifth as long as eyes length ; first and second antennal segments black, the latter with short bristles above and longer beneath ; third segment yellow, short acuminate, about twice as deep as the second ; arista black, slightly longer than third segment.

Thorax and scutellum black, with brownish dust on dorsurn ; notopleuron cinereous ; humeri black ; propleural fan pale.

Legs almost entirely yellow except coxae and last tarsal segment black.

Wings hyaline ; stigma brownish, extending back to tip of Sc; third costal section about 1.6 times as long as fourth ; r-m situated slightly after middle of discal medial cell ; last section of vein Ml slightly undulating; halteres dark brown ; calypteres yellowish brown.

Abdomen slightly longer than thorax, when viewed from above tergites 2-5 polished black; tergite 1 cinereous, with a brush of some short black bristles anterolaterally ; tergites $1-4$ almost equal in size, tergite 5 largest, about twice as long as the tergite 1 ; tergite 8 (Figs. $42 \mathrm{~F}, 43 \mathrm{D}$ and $44 \mathrm{G}$ ) rather small, dull brownish black, with large membranous area ; this area occupying more than half of segment on the right side, pentagonal shape.

Genitalia with epandrium and surstyli very much protruded as seen from side, black in color ; surstyli (Fig. 43D) symmetrical, rather large when compared with its epandrium.

Length : Body $3.8 \mathrm{~mm}$; wing $5.0 \mathrm{~mm}$.

Holotype: $\sigma^{7}$ (Type No. 2731, Kyushu Univ.), Boudou-toge, Asahi-mura, Niigata, Honshu, 2, vii. 1985 (R. Morakote).

Paratypes: 1ð7, Gamusi, Hokkaido, 12. vii. 1958 (T. Kumata) ;1 $\sigma^{7}$, Koshima, Yakushima Island, Kagoshima Pref., Kyushu, 8. vii. 1970 (K. Tobi).

Host : Unknown.

Distribution : Japan (Honshu, Kyushu).

Cephalops incohatus Morakote, sp. $\mathrm{n}$.

Male.

Differing from the male of C. annulipes as follows: Third antennal segment short acuminate ; femora entirely yellow ; apex of subcostal vein not reaching to costal 
vein ; abdominal tergites $1-4$ with a contrasting band of black anteriorly and conspicuously grey posteriorly, spasrely covered with short pubescence ; abdominal terminalia as shown in Figs. 42B and 44A ; genitalia with epandrium and surstyli very much protruding as seen from side.

Length : Body $6 \mathrm{~mm}$; wing $7 \mathrm{~mm}$.

Holotype: đ7 (Type No. 2732 ; Kyushu Univ.), Yawate, Kyoto Pref., 10. vii. 1987 (Y. Y oshiyasu).

Host : Unknown.

Distribution : Japan (Honshu).

Cephalops yoshiyasui Morakote, sp. n.

\section{Male.}

This species differs from the male of C. pacatus as follows : Abdominal tergites 1 -4 with a contrasting band of black anteriorly and conspicuously grey posteriorly, sparsely covered with short pubescence; r-m of wing situated at basal one-third of discal medial cell ; genital surstyli and epandrium (Fig. 44B) clearly different from that of C. pacatus.

Length : Body $4.7 \mathrm{~mm}$; wing $5 \mathrm{~mm}$.

Holotype: $\sigma^{7}$ (Type No. 2733, Kyushu Univ.), Yawate, Kyoto Pref., 10. vii. 1987 (Y. $\mathrm{Y}$ oshiyasu).

Host : Unknown.

Distribution : Japan (Honshu).

Cephalops kumatai Morakote, sp. n.

\section{Male.}

Head and thorax almost similar to that of C. annulipes but different by having the yellowish third antennal segment. Propleural fan rather short, pale in color.

Legs with black coxae; femora mainly black except at extreme one-seventh of base and tip yellowish ; trochanters, tibiae and tarsi yellow except last tarsal segment blackish.

Wings hyaline, stigma brownish, extending back to tip of $\mathrm{Sc}_{\mathrm{C}}$, about as long a fourth ; r-m situated much after basal third of discal cell ; last section of vein Ml slightly undulating, shape of cell R5 decidedly different from that of other species.

Abdomen rather long, parallel-sided ; abdominal tergites brownish with conspicuous fine dusting; tergites 1-4 almost equal in size ; tergite 5 longest, about twice as long as tergite 4 ; tergite 8 small, about half as long as tergite 8 , compressed to the right, with oval membranous area at apex which is clearly seen only from behind ; abdominal terminalia as shown in Figs. $42 \mathrm{H}$ and $44 \mathrm{C}$; surstyli clearly different from other species in the genus.

Length : Body $4 \mathrm{~mm}$; wing $5 \mathrm{~mm}$.

Holotype: đ7, Apoi, Hokkaido, 22. vi. 1959 (T. Kumata), in the collection of Hokkaido University.

Paratype: ð7, Aizankei, Hokkaido, 16. vii. 1960 (S. Takagi).

Host : Unknown. 
Distribution : Japan (Hokkaido).

\section{Cephalups pulvillatus (Kertész)}

Dorylas pulvillatus Kertész, 1915, Ann. Hist. Nat. Mus. Natl. Hungarici, 13 : 387.

Pipunculus (Cephalops) pulvillatus: Hardy, 1972, Oriental insects, suppl., $2: 27$.

This species has been recorded to found from Japan (Okinawa) and well described by Hardy (1972).

Host : Unknown.

Distribution : Japan (Okinawa), Taiwan, Philippines and Thailand. 


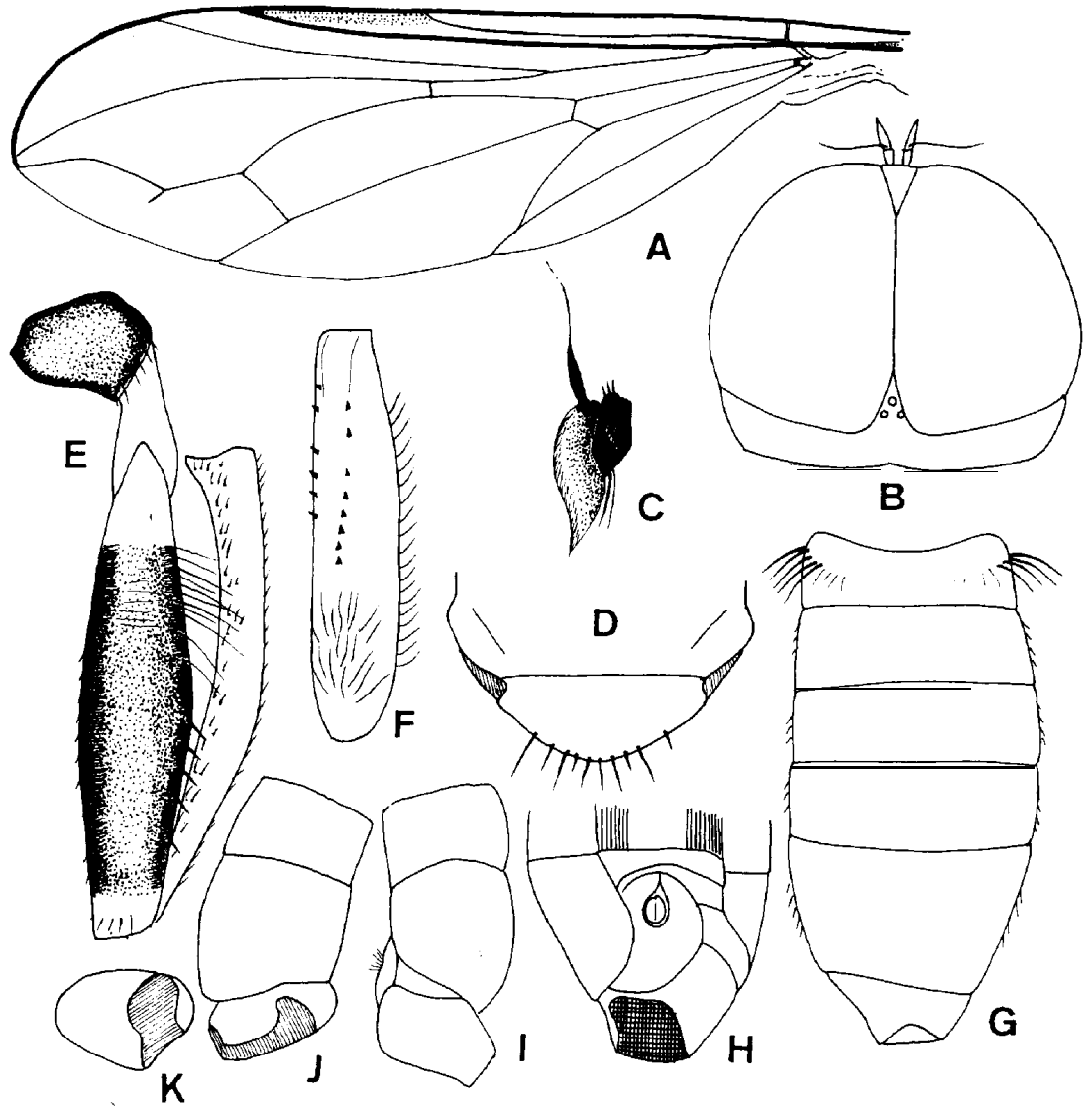

Fig. 29. Cephalops furcatus (Egger) (male) : A. Wing ; B. head, dorsal ; C. antenna ; D. scutellum, dorsal ; E. hind leg ; F. mid femur, beneath ; G. abdomen, dorsal ; H-J. abdominal terminalia, ventral ; I. ditto, left side ; J. ditto right side ; K. tergite 8 , behind. 


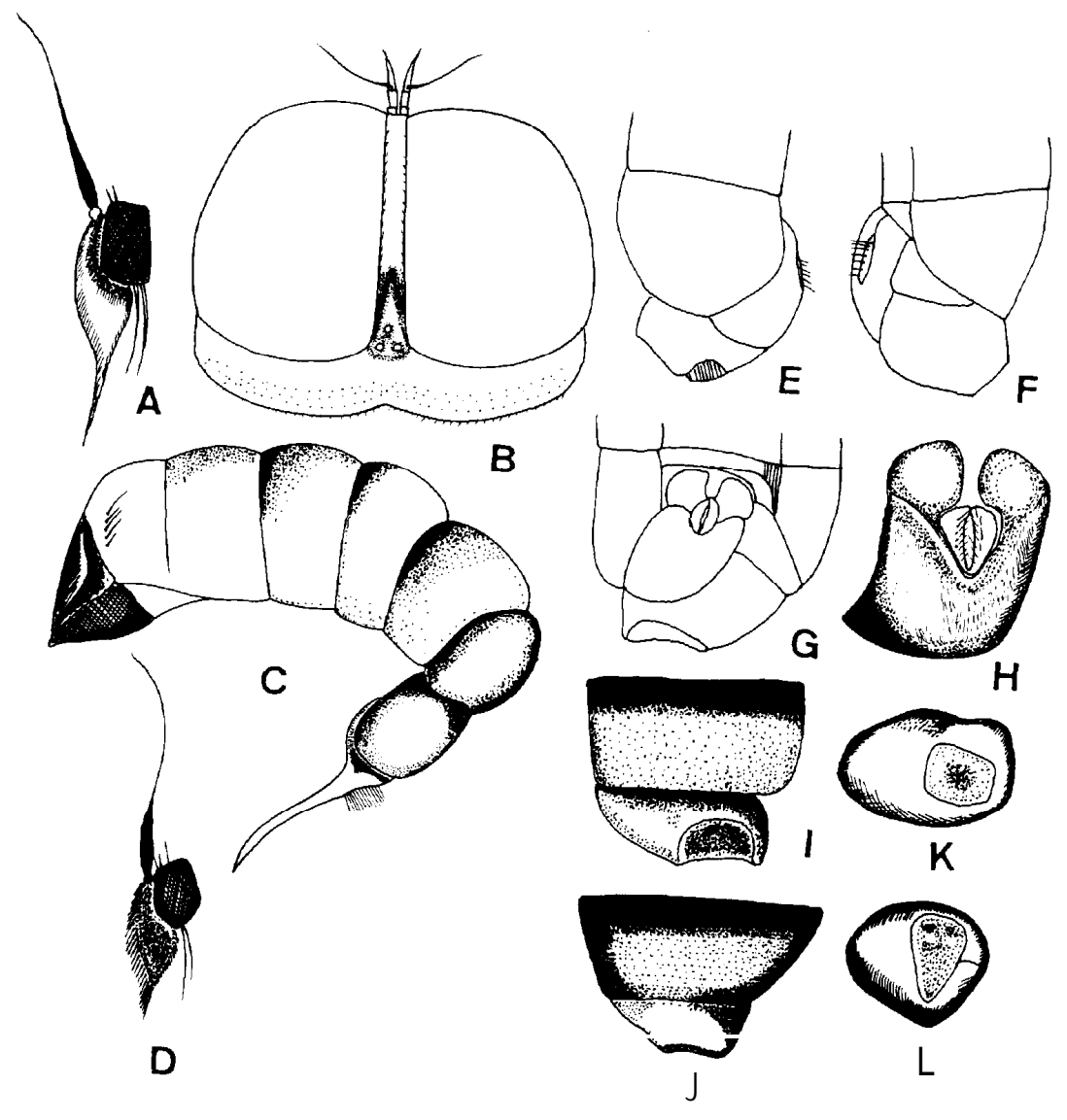

Fig. 30. A-C. Cephalops furcatus (Egger) (female) : A. Antenna ; B. head, dorsal ; C. abdomen, lateral. D-L. C. hirashimai Morakote, sp. n. (male) : D. antenna ; E-G. abdominal terminalia (E. right side, F. left side, G. ventral) ; H. epandrium and surstyli, dorsal ; I-J. abdominal terminalia, dorsal ; K-L. segment 8 , behind. 


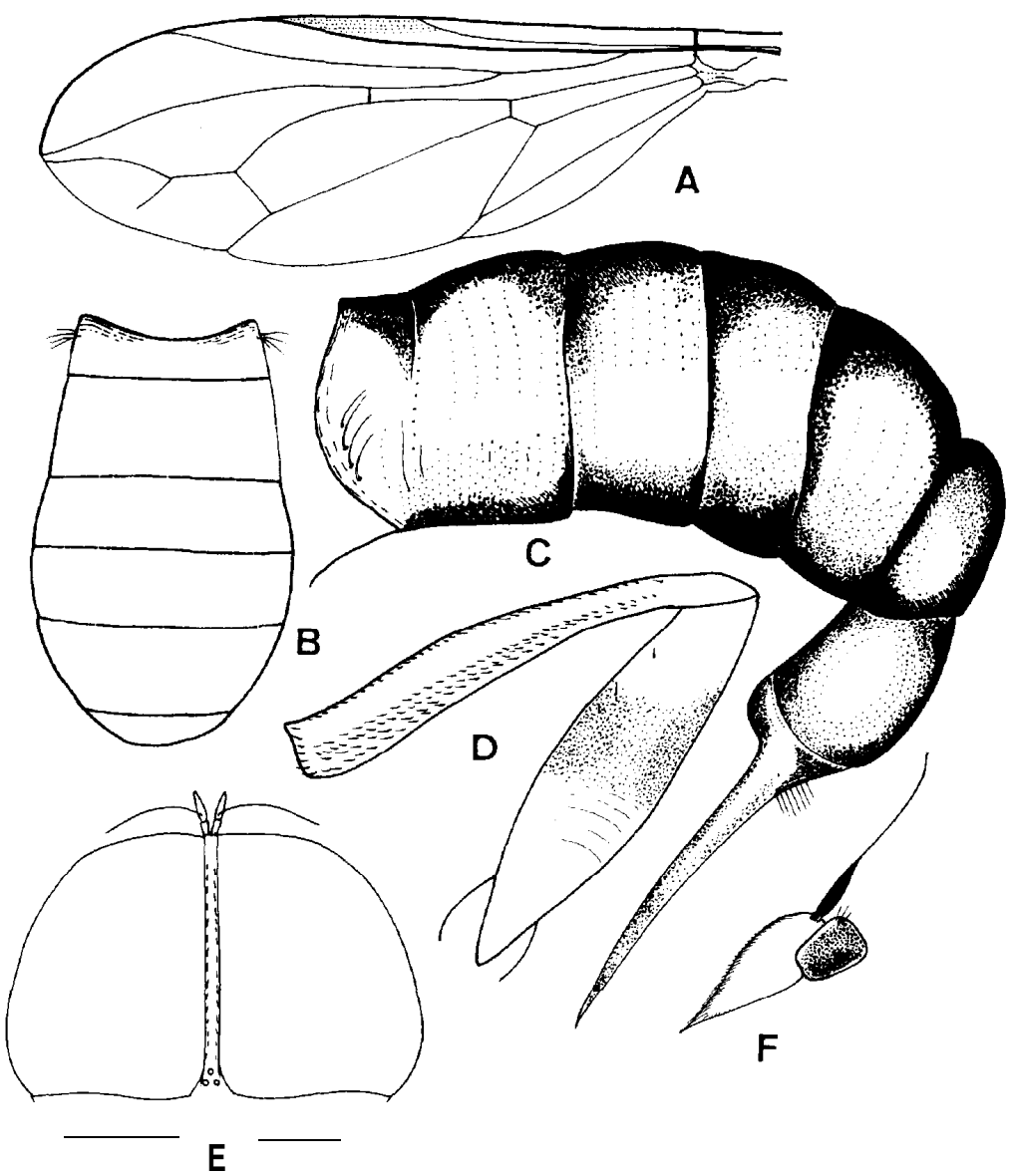

Fig. 31. Cephalops hikosanus Morakote, sp. n. (female) : A. Wing ; B. and C. abdomen (C. dorsal, D. lateral) ; D, hind leg ; E. head, dorsal ; F. antenna. 


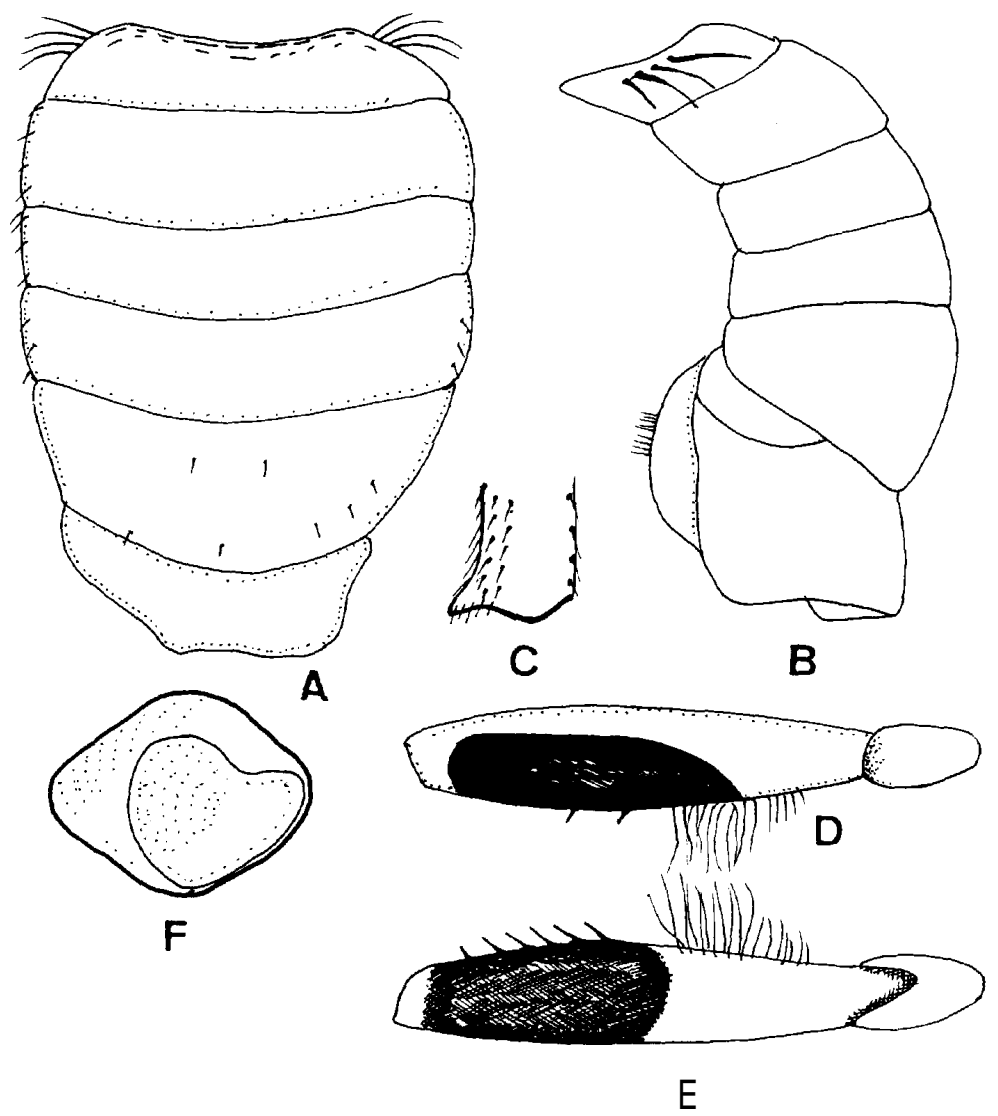

Fig. 32. Cephalops sapporoensis Morakote, sp. n. (male): A-B. Abdomen (A. dorsal, B. left side) ; C. apex of hind tibiae, lateral ; D-E. hind femur (D. posterior, E. anterior) ; F. abdominal segment 8 , behind. 


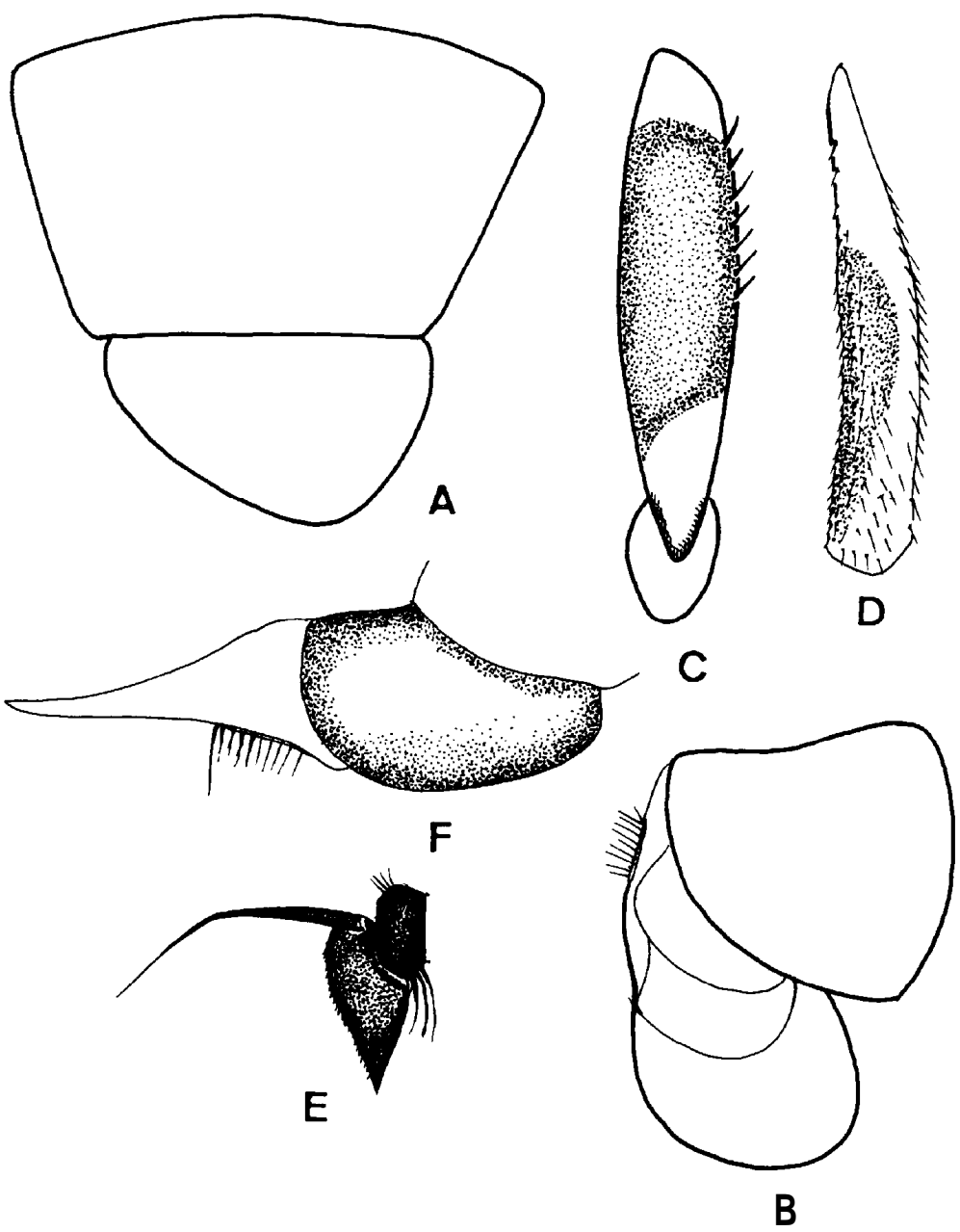

Fig. 33. Cephalops honshuensis Morakote, sp. n.: A-B. Male abdominal terminalia (A. dorsal, B. left side) ; C. hind femur, anterior; D. tibia, anterior; E. antenna ; F. female ovipositor, lateral. 

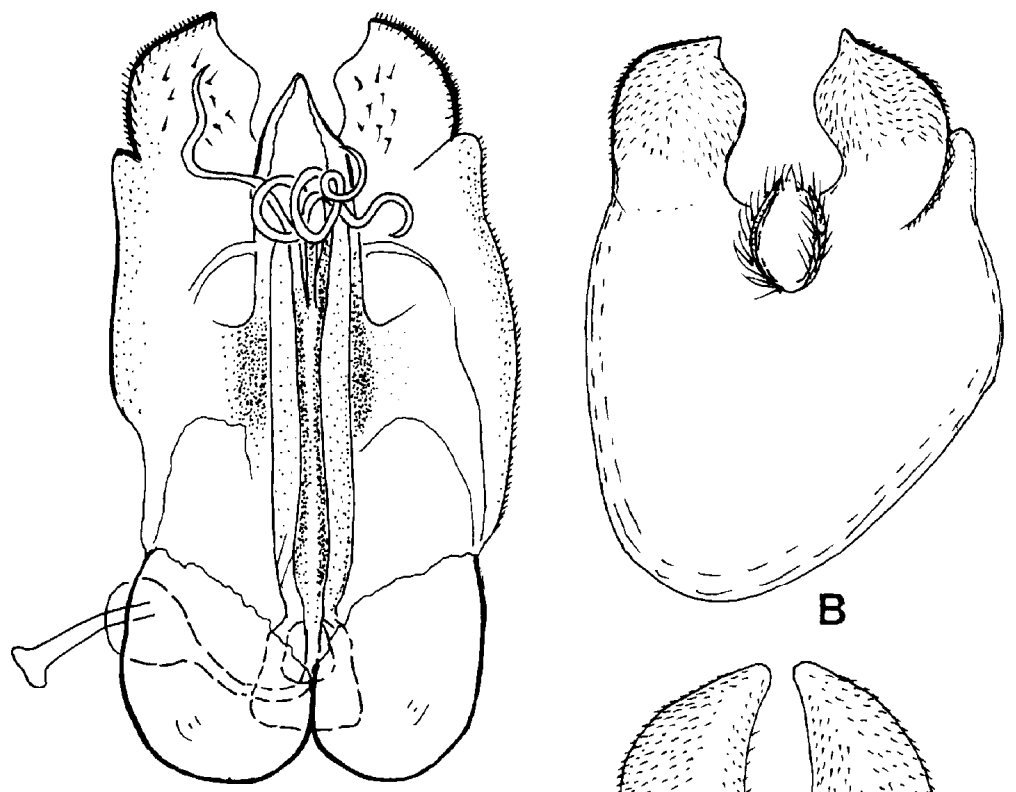

A

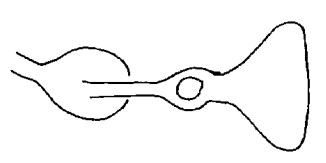

D

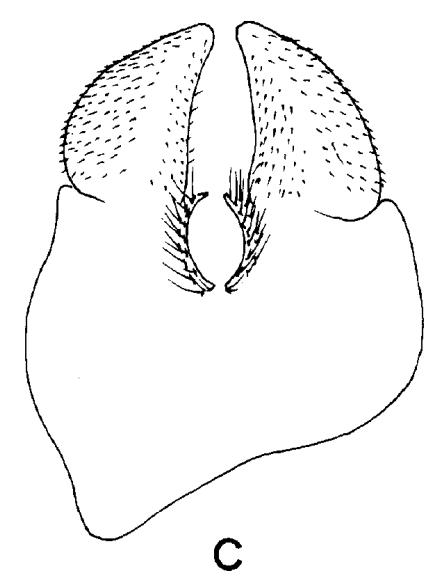

Fig. 34. A-B. Cephalops hirashimai Morakote, sp. n. (male) : A. Genitalia, dorsal ; B. epandrium and surstyli dorsal. C-D. Cephalops furcatus (Egger) (male) : C. ejaculartory apodeme ; D. epandrium and surstyli, dorsal. 


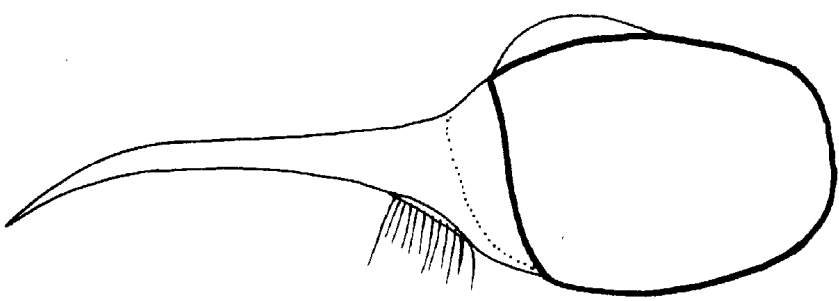

A
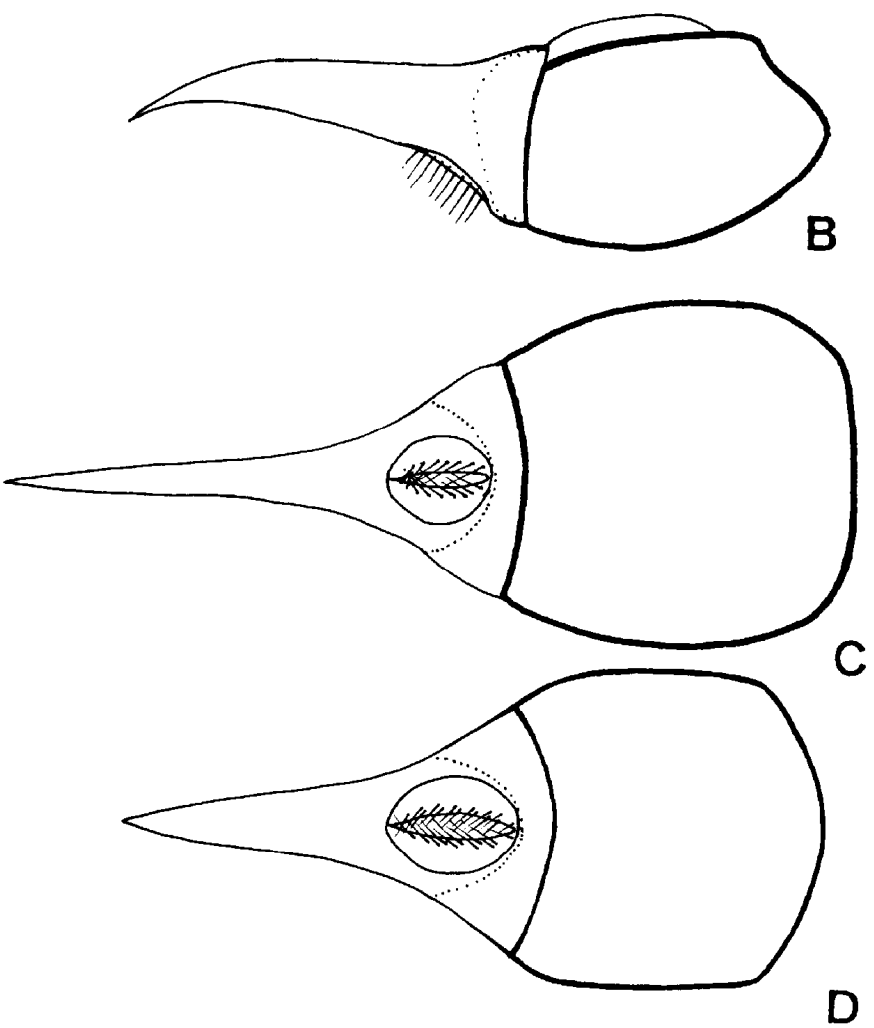

Fig. 35. A and C. Cephalops furcatus (Egger), female ovipositor: A. Lateral, C. ventral. B and D. C. hirashimai Morakote, sp. n., female ovipositor: B. lateral ; D. ventral. 


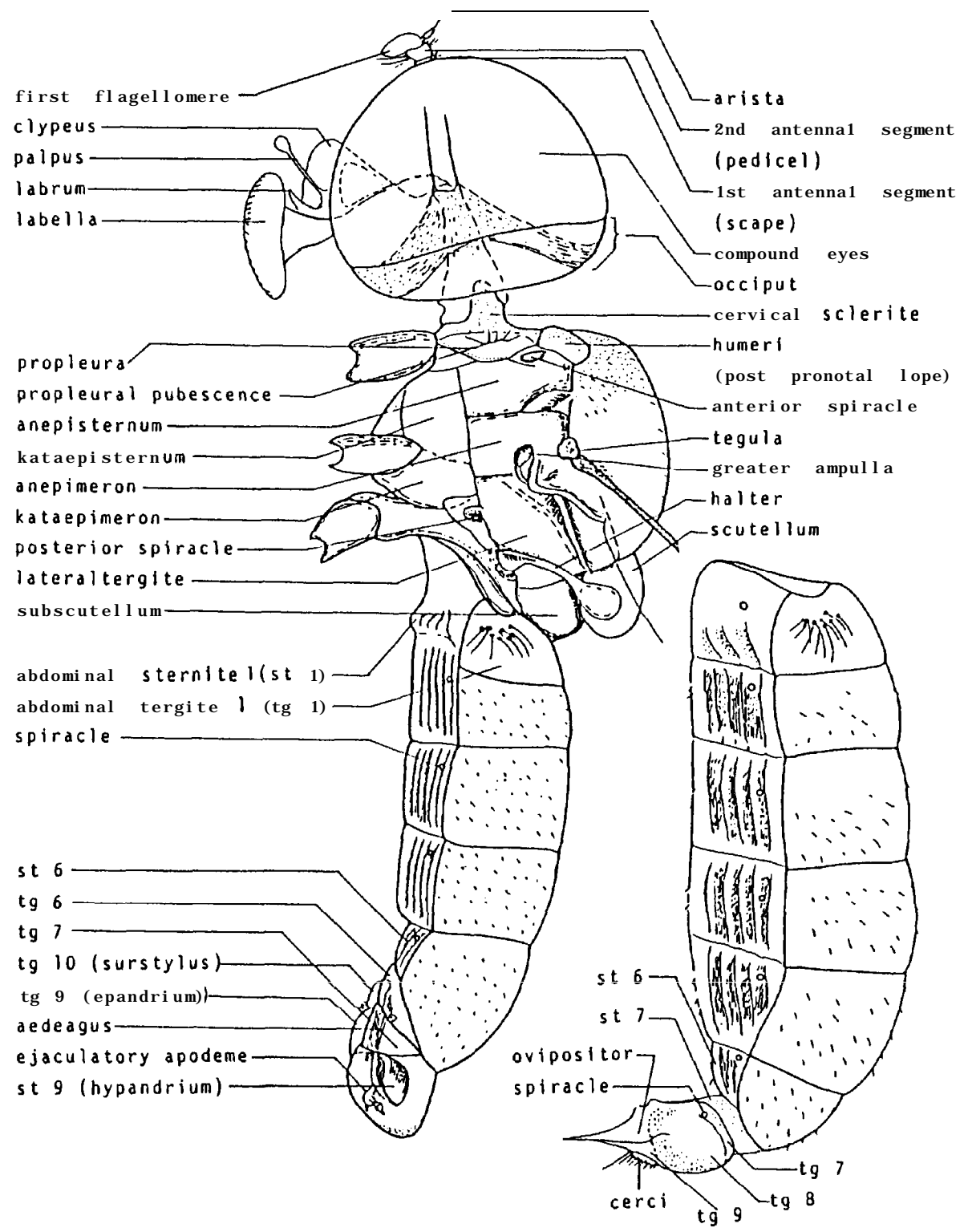

Fig. 36. Morphology of Cephalops annulipes (Zetterstedt) : A. Body of male, lateral ; B. famale abdomen, lateral. 


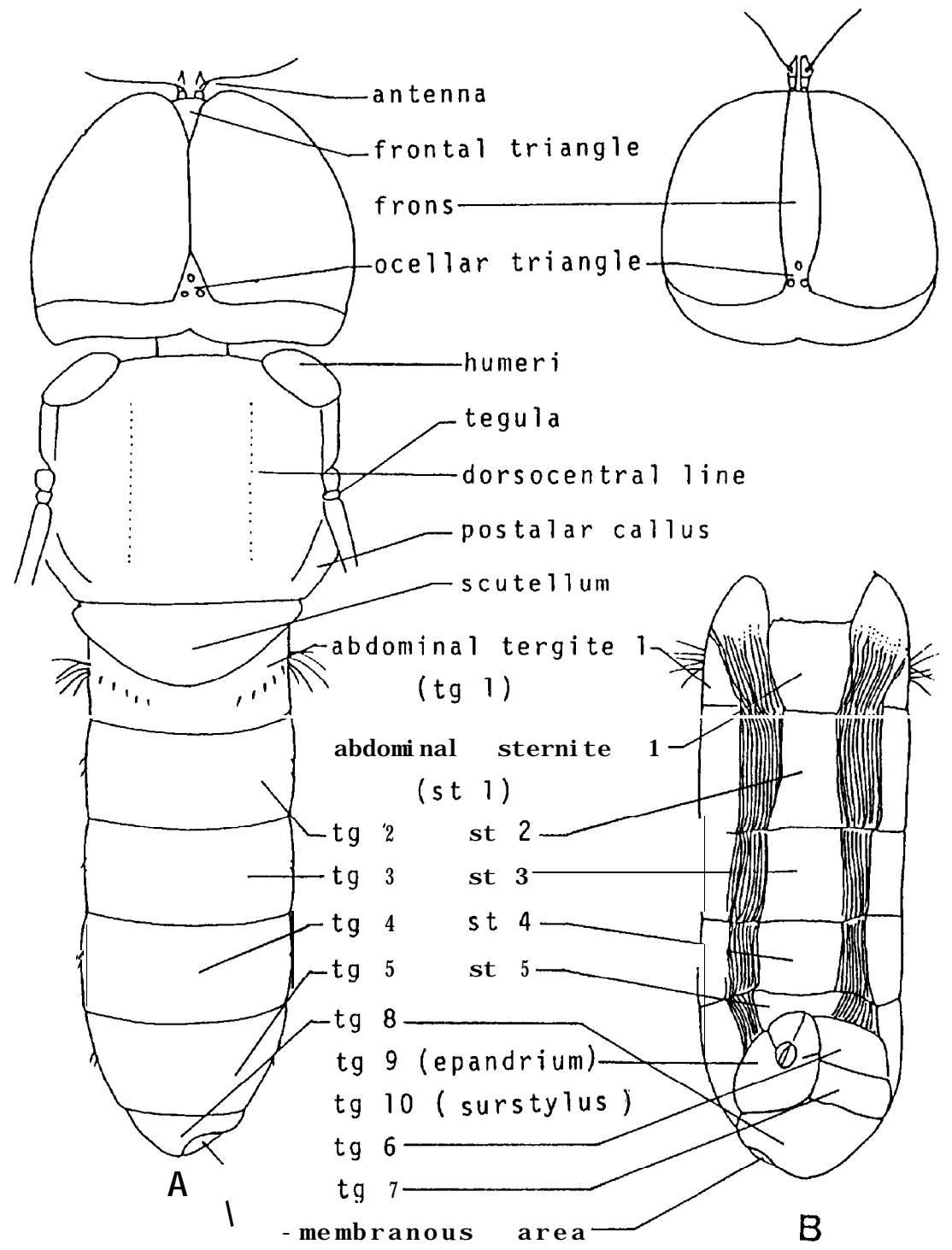

Fig. 37. External morphology of Cephalops annulipes (Zetterstedt) : A. Body of male, dorsal ; B. male abdomen, ventral ; C. head of female, dorsal. 


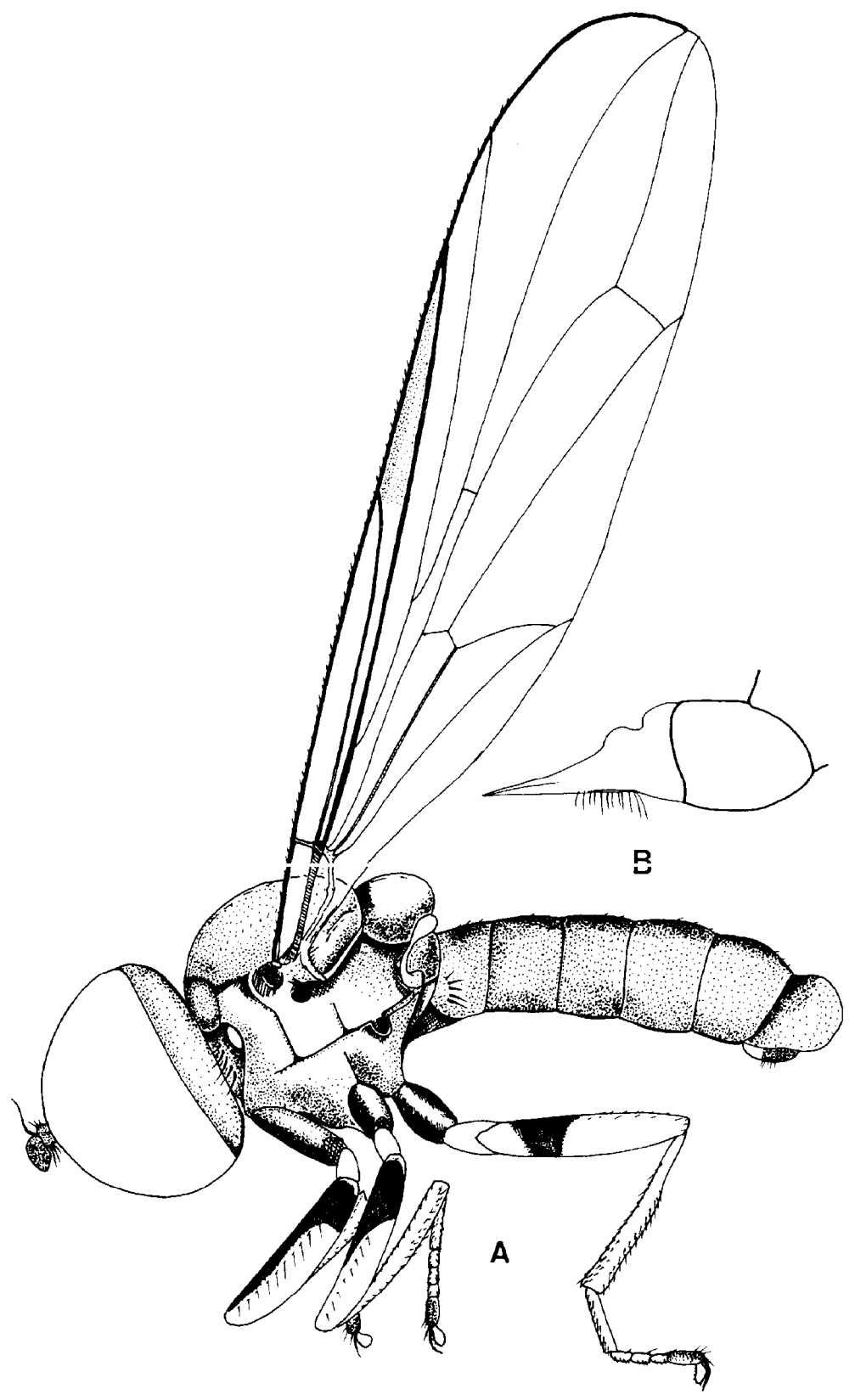

Fig. 38. Cephalops annulipes (Zetterstedt) : A. Male; B. female ovipositor, lateral. 


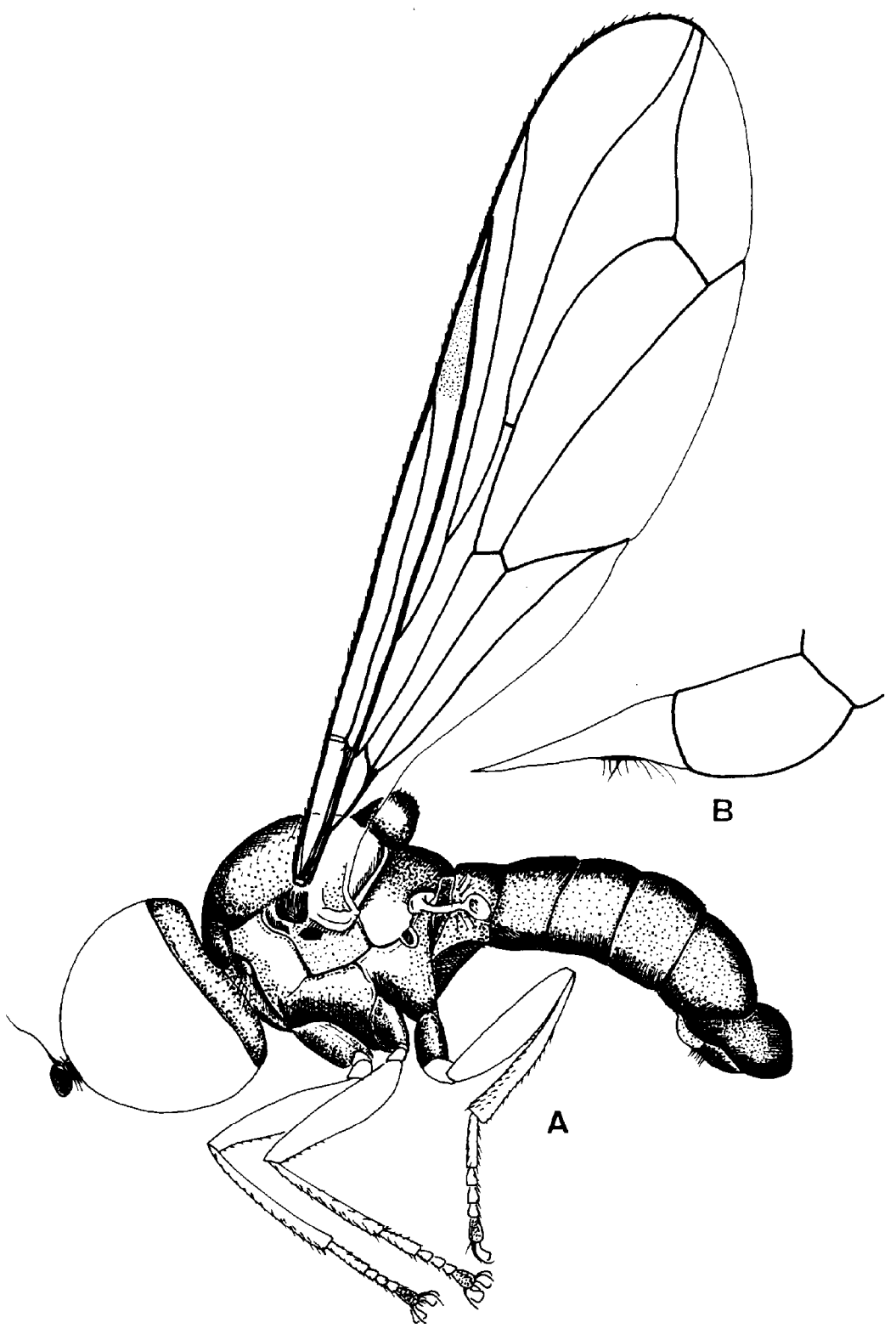

Fig. 39. Cephalops aneus Fallên: A. Male ; B. female ovipositor, lateral. 


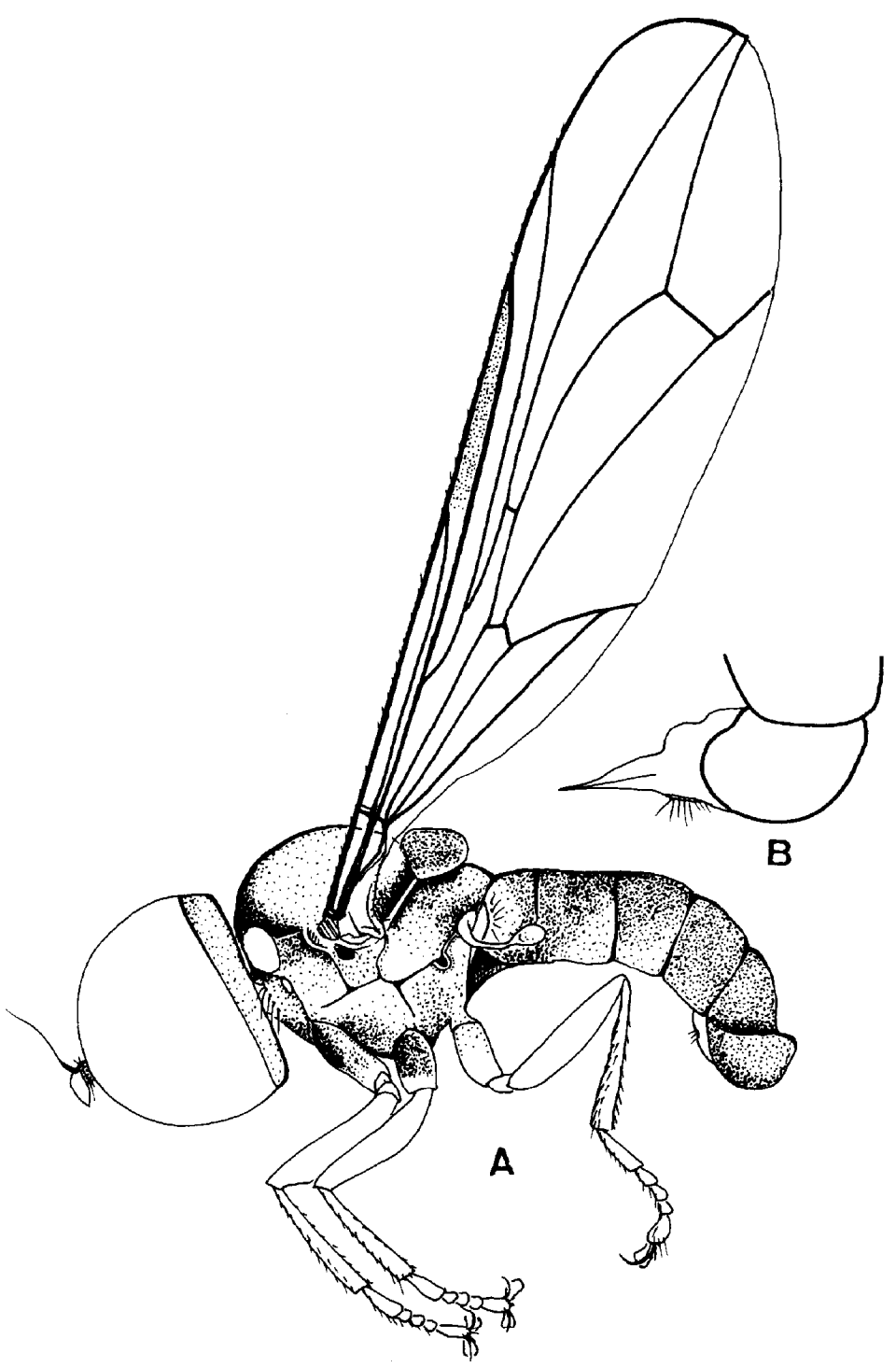

Fig. 40. Cephalops pacatus Morakote, sp. n.: A. Male ; B. female ovipositor, lateral. 

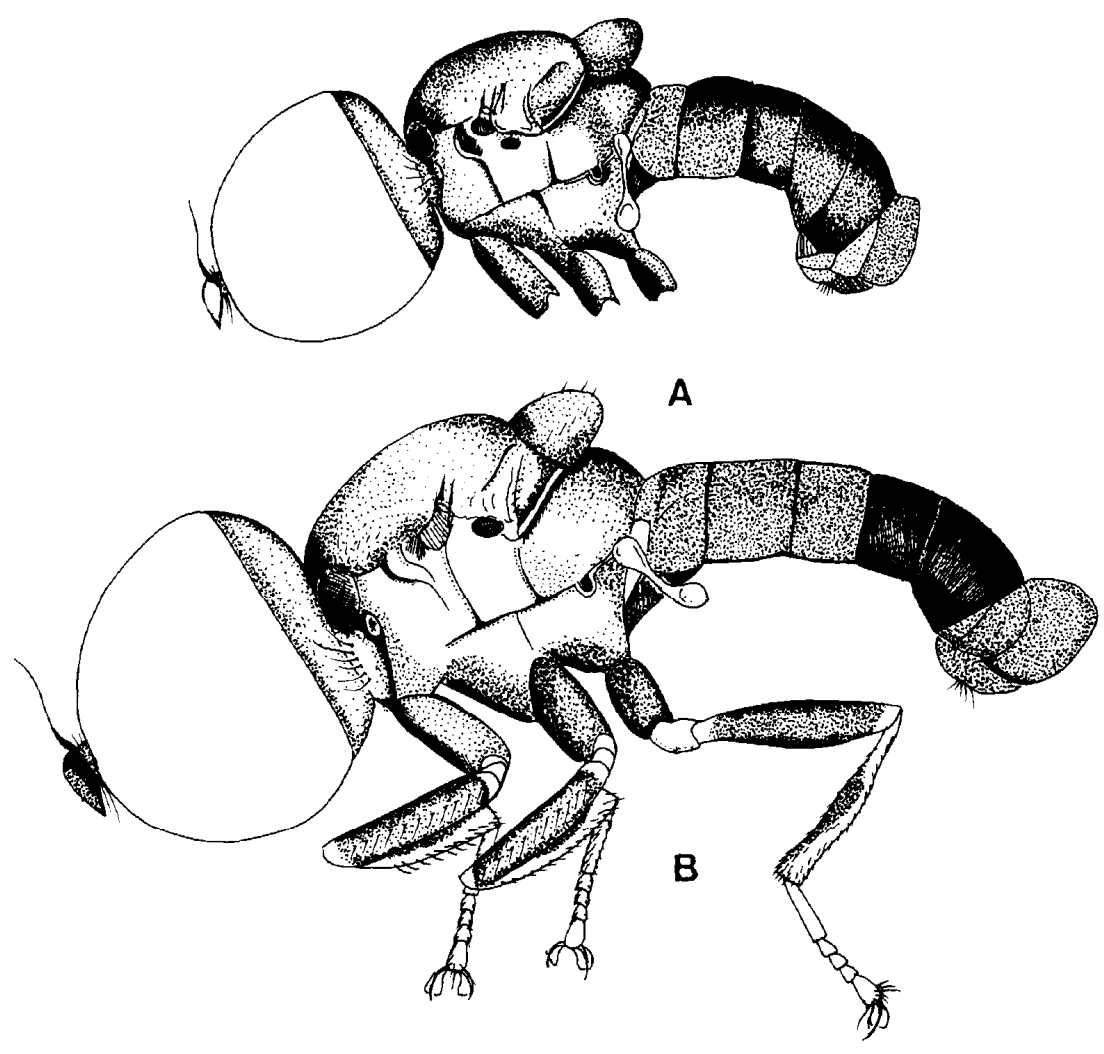

Fig. 41. A. Cephalops metallicus Morakote, sp. n. (male) ; B. C. obtusinervis (Zetterstedt). 


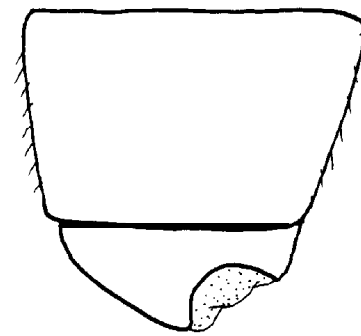

A

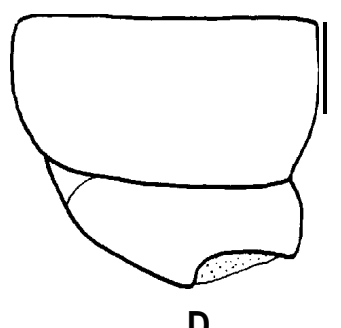

D

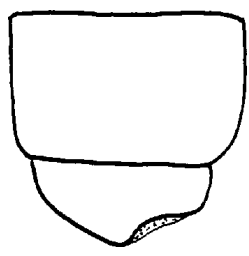

G

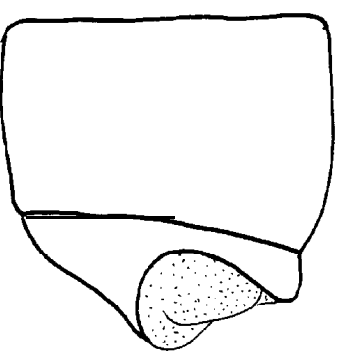

B

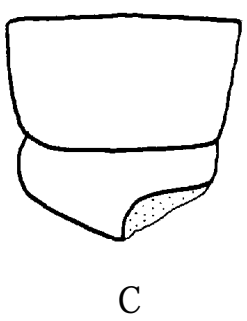

C

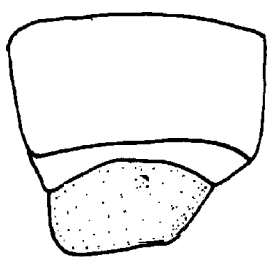

F

$E$

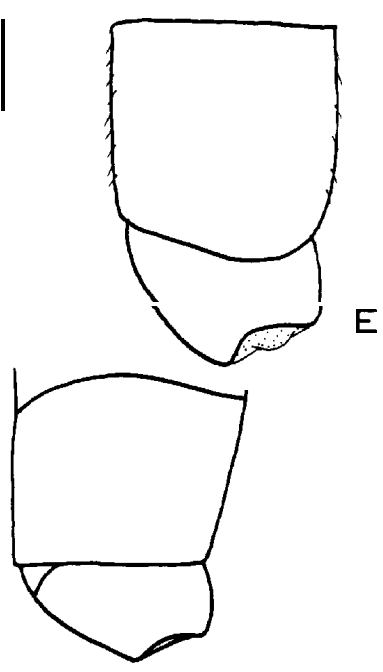

$\mathrm{H}$

Fig. 42. Male abdominal terminalia of Cephalops spp., dorsal : A. annulipes (Zetterstedt) ; B. incohatus Morakote, sp. n. ; C. obtusinervis (Zetterstedt) ; D. yoshiyasui Morakote, sp. n. ; E. aneus Fall\&n ; F. metallicus Morakote, sp. n. ; G. pacatus Morakote, sp. n. ; H. kumatai Morakote, sp. n. 


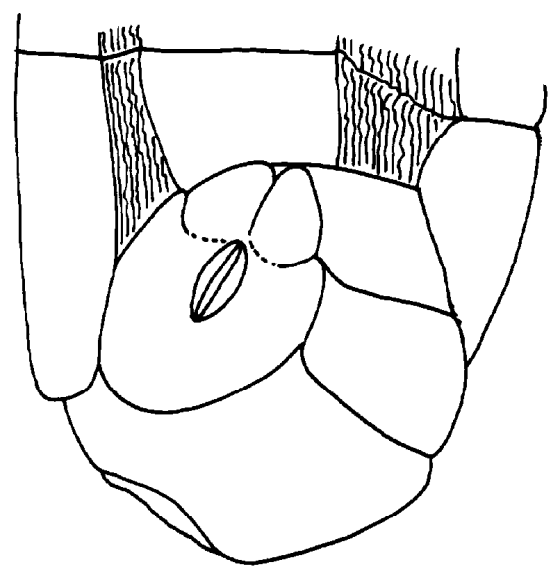

A

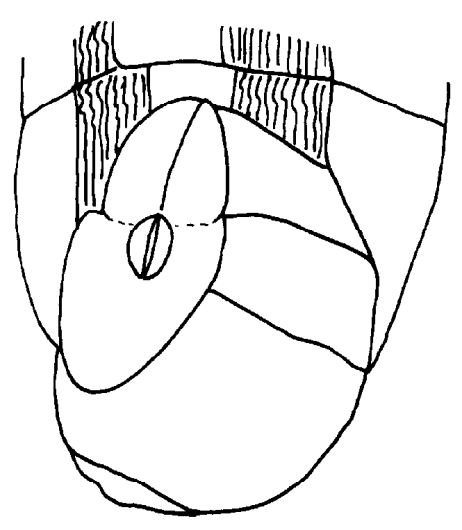

B

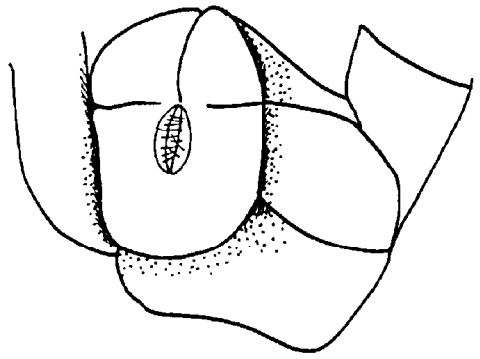

C

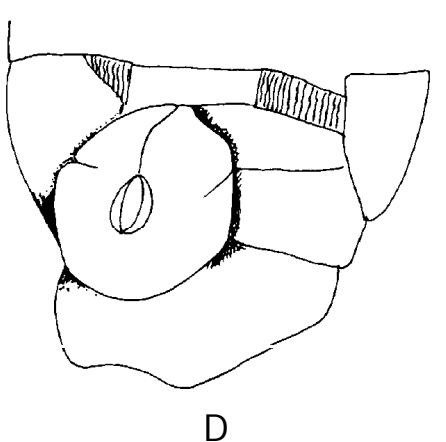

Fig. 43. Male abdominal terminalia of Cephalops spp., ventral : A. annulipes (Zetterstedt) ; B. aneus Fallén ; C. obtusinervis (Zetterstedt) ; D. metallicus Morakote, sp. n. 


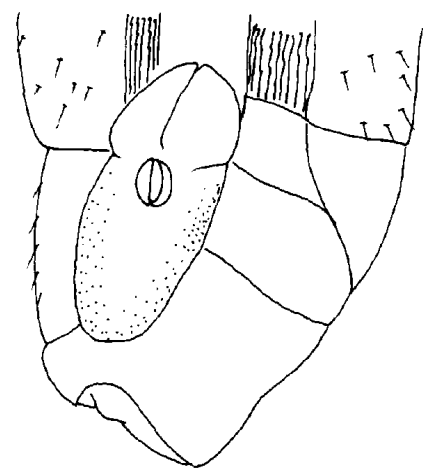

A

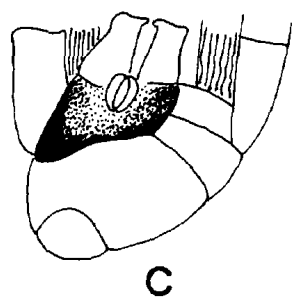

C

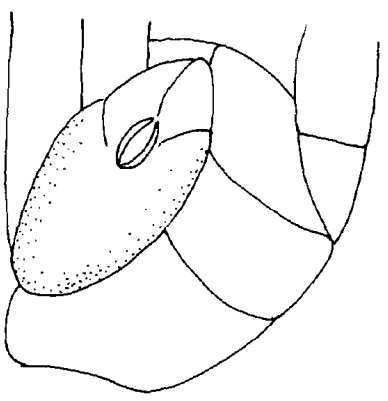

B

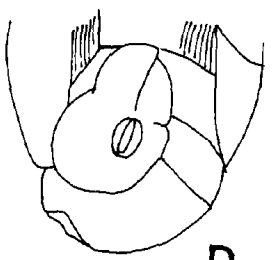

D
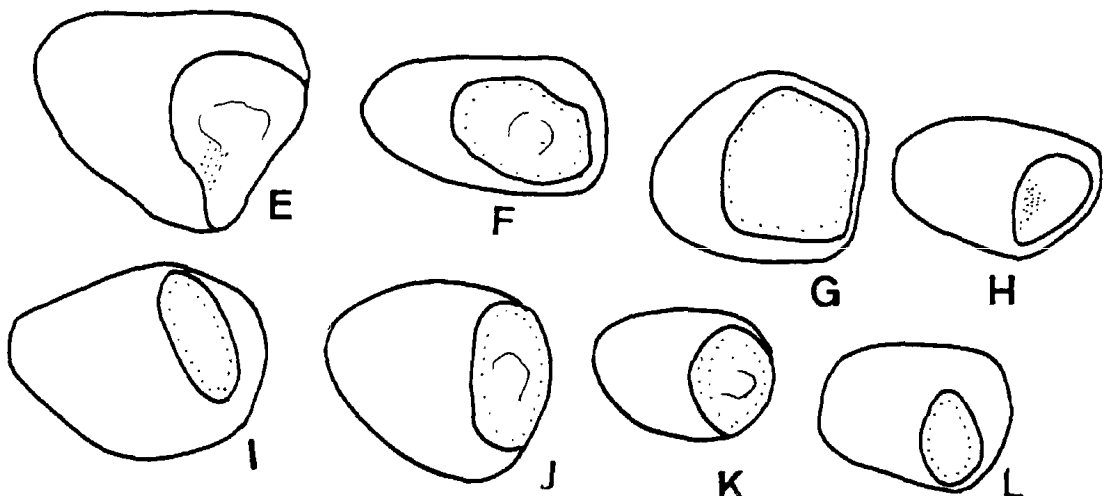

Fig. 44. A-D. Male abdominal terminalia of Cephalops spp., ventral : A. incohatus Morakote, sp. n. ; B. yoshiyasui Morakote, sp. n. ; C. kumatai Morakote, sp. n. ; D. pacatus Morakote, sp. n. E-L. Abdominal segment 8 of Cephalops spp., behind: E. incohatus, F. aneus Fall\&n. ; G. metallicus Morakote, sp. n. ; H. obtusinervis (Zetterstedt); I. yoshiyasui ; J. annulipes (Zetterstedt) ; K. pacatus ; L. kumatai. 

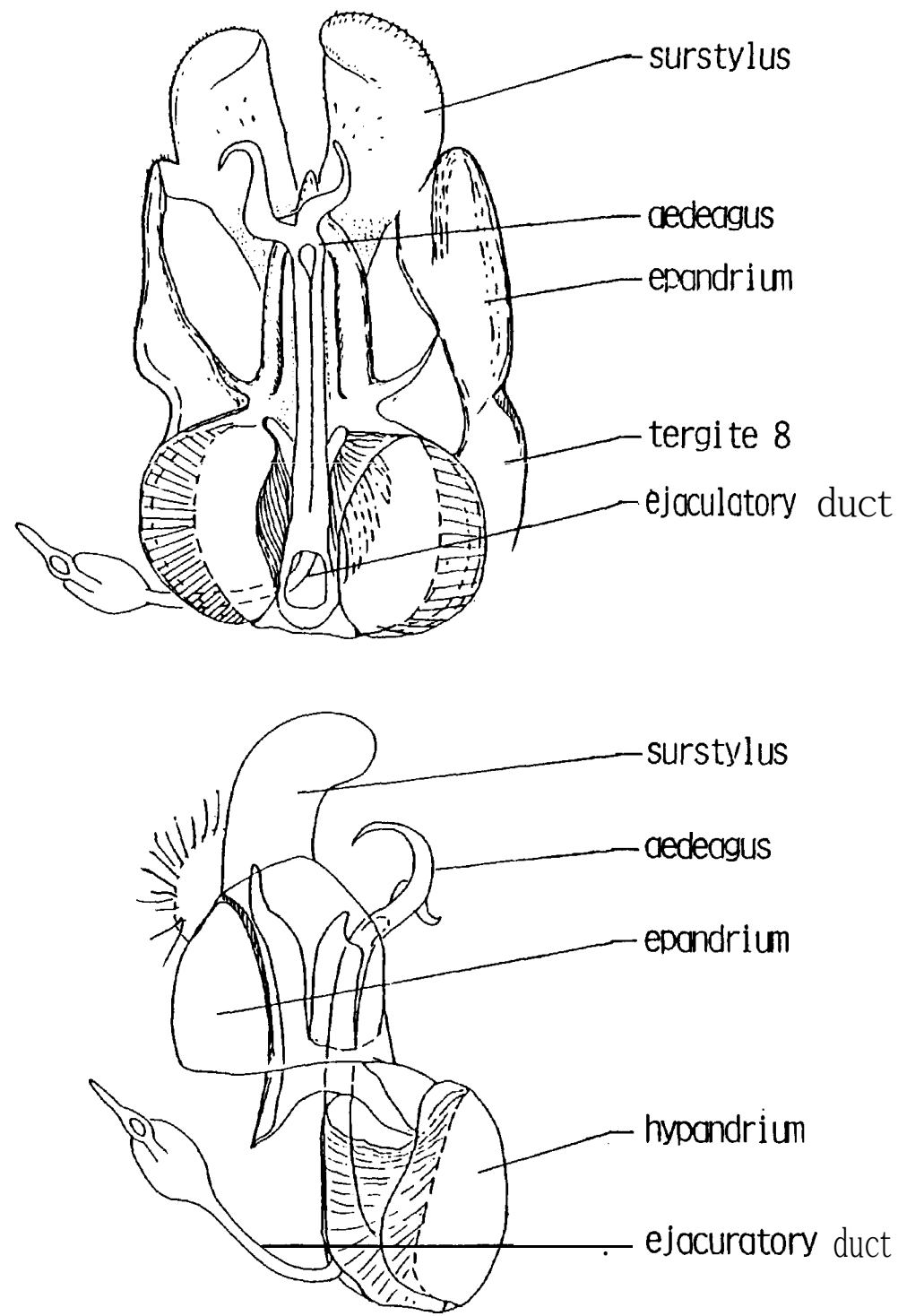

Fig. 45. Male genitalia of Cephalops annulipes (Zetterstedt): A. Dorsal, B. lateral. 

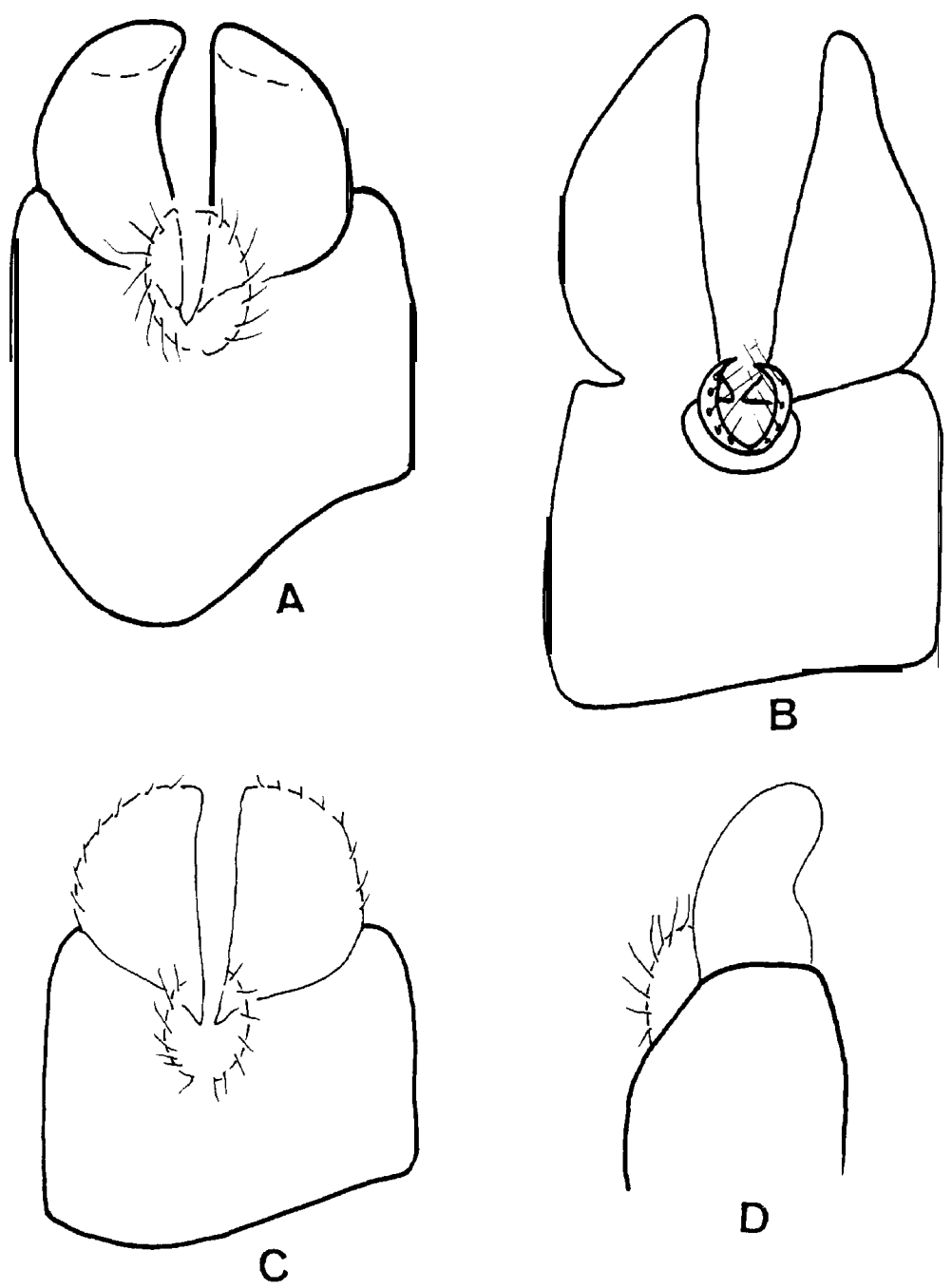

Fig. 46. Epandrium and surstyli of Cephalops spp., dorsal : A. annulipes (Zetterstedt) ; B. aneus Fallén; C and D. pacatus Morakote, sp. n. 